\title{
Comparative exergy and exergy efficiency analyses of fabricated single and double slope solar still plants at Indore: case study
}

\author{
Ankur Geete $^{1} \cdot$ Devesh Kharve $^{1} \cdot$ Hemant Patel $^{1} \cdot$ Hansraj Karma $^{1} \cdot$ Ashok Prajapati $^{1} \cdot$ Shubham Sharma $^{1}$
}

Received: 22 August 2019 / Accepted: 15 April 2020 / Published online: 25 April 2020

(c) Springer Nature Switzerland AG 2020

\begin{abstract}
In this research project two solar still plants have been fabricated; single and double slope still plants. The exergy and exergy efficiency concepts have been applied for the comparative analyses of both solar stills. Experimental readings, i.e. various temperatures, amounts of distilled water and solar radiations have been taken for solar stills at different time intervals in Indore ( $22^{\circ} 43^{\prime} 4.51^{\prime \prime} \mathrm{N}$ and $\left.75^{\circ} 49^{\prime} 59.88^{\prime \prime} \mathrm{E}\right)$. The percentage variations in the different parameters, i.e. increments in temperature, increments in quantity of water, thermal efficiencies, rates of exergy at inlet/outlet and exergy efficiencies have also been calculated for stills at various solar intensities and time intervals. After experimental and comparative analyses, better outputs have been shown at 14:50 PM for double slope and 14:45 PM for single slope plant due to the cumulative effects of solar radiations on the still plants. During this period thermal/exergy efficiencies, i.e. $46.630 / 1.949 \%$ and $47.259 / 3.389 \%$ were found the best. The performance of single slope solar still has been found better, and 14:30 to 14:50 PM time interval has been recorded superior for the distillation of water through still plants where percentage increments of the performance evaluating parameters were enhanced.
\end{abstract}

Keywords Single and double slope solar stills · Thermal efficiency · Rates of inlet and outlet exergy · Exergy efficiency · Solar radiation

\section{List of symbols}

C Specific heat of water (J/kg K)

$d T_{w} \quad$ Temperature difference which was achieved due to solar energy $(\mathrm{K})$

$I_{b} R_{B} \quad$ Solar radiation which is available for single and double slope solar still $\left(\mathrm{W} / \mathrm{m}^{2}\right)$

$L \quad$ Length of the solar still $(\mathrm{m})$

$m \quad$ Mass flow rate of pure water $(\mathrm{kg} / \mathrm{s})$

$T_{0,} T_{w}$ and $T_{s} \quad$ Ambient, water and Sun's surface temperatures $(\mathrm{K})$

W Width of the solar still (m)

\author{
Greek symbols \\ $\eta \quad$ Thermal efficiency of the solar still (\%) \\ $a_{g}, \rho_{g}$ and $\tau_{g}$ Absorptivity, reflectivity and transmissiv- \\ ity of the glass \\ $\psi_{\text {in }}$ and $\psi_{\text {out }} \quad$ Exergy at inlet and outlet for single and \\ double slope solar still (W)
}

\section{Introduction}

A technology has been developed by the researchers for the purification of water which is simple, economical and also eco-friendly. This technology is based on the solar energy. Solar still plant is used to purify the water by heat of the Sun [1]. In this still plant the water evaporates and this water vapour goes upside where the tilted glass is placed. At the glass surface, water condenses and

Ankur Geete, ankur_geete@yahoo.co.in | ${ }^{1}$ Mechanical Engineering Department, Sushila Devi Bansal College of Technology, Indore, Madhya Pradesh, 453331, India. 
in this process all impurities like salts, heavy metals and the microbiological element/organism are removed from water. Due to gravitational activity, the purest water collects in the container which is cleaner than the rain water [1-4]. Solar distillation plants are used for industrial processes, in hospitals for the sterilization, in automobile workshops for the radiator and battery maintenance and also in the laboratories. The benefits of these distillation plants are: pure water is produced for the drinking purpose, very less or negligible maintenance cost is required, impure water is easily purified into potable water, moving/ rotating components are not used in these type of plants so no electricity is required to operate them, minimum wastage of water is recorded and no skilled operator is required. There are two types of solar stills which have been generally used for the purification of water [1-4]; (a) basin type solar still that consists shallow bracken basin of impure water with transparent rooftop (i.e. Glass) at an angle which is used to pass solar radiation for the evaporation of impure water. On the inner surface of the rooftop, evaporated water condenses and slides on the surface of the rooftop due to gravity and pure water collects in the tank, and (b) wick type solar still which consists a wick and impure water that passes through the wick where the water is absorbed by capillary action. Solar energy is absorbed by the water which is present in the wick and that water evaporates then condenses and finally pure water collects in the tank. In this research work basin type solar still has been used and important components of basin type solar still are; (1) still basin-impure water is kept in this section and the maximum amount of solar radiation is absorbed by the water here, so it is very essential that the selected material should have high absorptivity and negligible reflectivity/transmissivity. Materials which can be selected for the basin are-leather sheet, Germanium silicon, mild steel plate, reinforced plastic and galvanized iron. In this experimental work $3 \mathrm{~mm}$ thick blackened galvanized iron sheet (thermal conductivity $300 \mathrm{~W} / \mathrm{m}-\mathrm{K}$ ) is used, (2) sidewalls - thermal resistance is provided by this wall, otherwise heat will be transferred from the basin to the surrounding. The wall must be made of that material which has low thermal conductivity or high thermal resistance. Materials which may be chosen for side walls are-wood, concrete, thermocol and reinforced plastic. In this experimental work, composite wall is manufactured where thermocol is placed at inside and wood is placed at the outside of the wall, i.e. $8 \mathrm{~mm}$ thick wood (thermal conductivity, $0.6 \mathrm{~W} / \mathrm{mK}$ ) and $15 \mathrm{~mm}$ thick thermocol (thermal conductivity, $0.02 \mathrm{~W} / \mathrm{mK}$ ) are used for the wall, (3) top cover-from the top cover, solar radiation is passed to the water so high transmissive material must be used for cover and after evaporation, water is condensed at inner surface of this top cover so it must be neither absorbent and nor adsorbent. Materials can be used as top cover are-glass and polythene with clean and smooth surface. In this work, $5 \mathrm{~mm}$ thick glass plate is installed on the basin of the solar still with rubber tube as frame border, and (4) channel-pure condensed water which appeared on the inner surface of the tilted glass is glided and collected in the passage called channel. Materials for the channel are-poly vinyl chloride (P.V.C.) and galvanized iron (G.I.) but here P.V.C. pipe is used as channel material [1-4]. Single and double slope solar stills have been shown in Fig. 1 [1-4]. Fabricated single and double solar stills have been shown in Figs. 2 and 3, respectively.

The maximum temperature difference between feed water and collected water is required to achieve high efficiency of solar still with low leakages of heat and water from the system, and high feed water temperature is also required for the same. High feed water temperature can be obtained through better solar radiation absorption and better thermal resistive surfaces of the side walls but less temperature of glass surface can be achieved by poor radiation absorbing surface. Some research manuscripts have been reviewed before doing this experimental work; performance analyses have been done on various single slope solar still plants at different climatic conditions with modified designs by numerical, modeling or experimental approaches [5-14]. Similarly, various analyses have also been performed on different double slope solar still plants separately with minimum basin depth, different energy

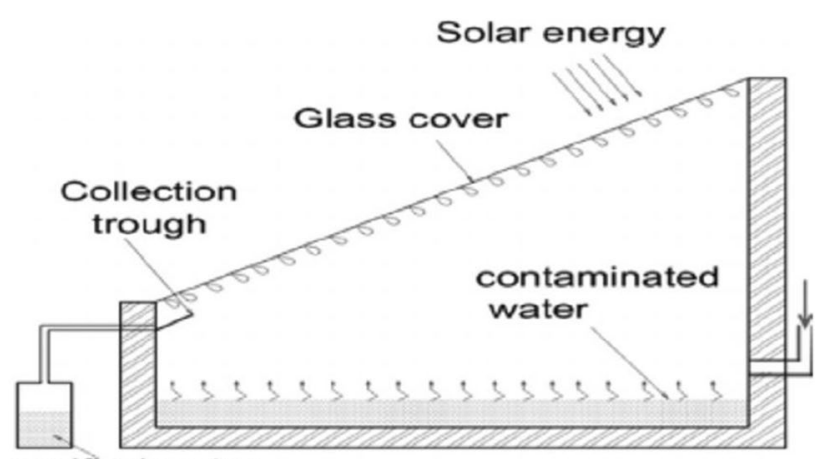

purified water

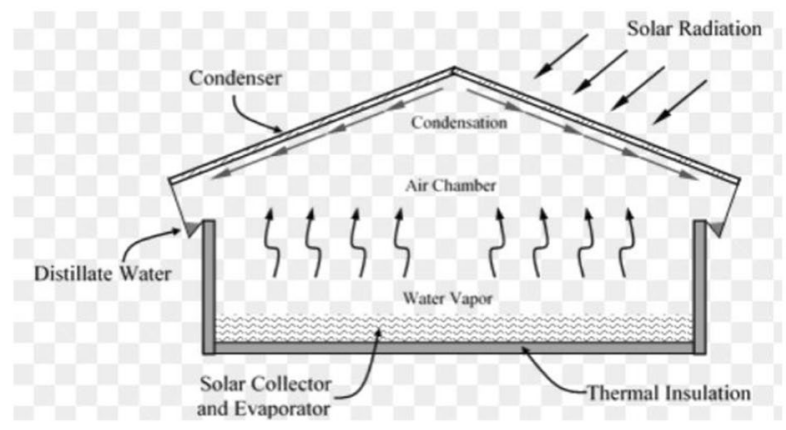

Fig. 1 Single and double slope solar stills distillation layout 


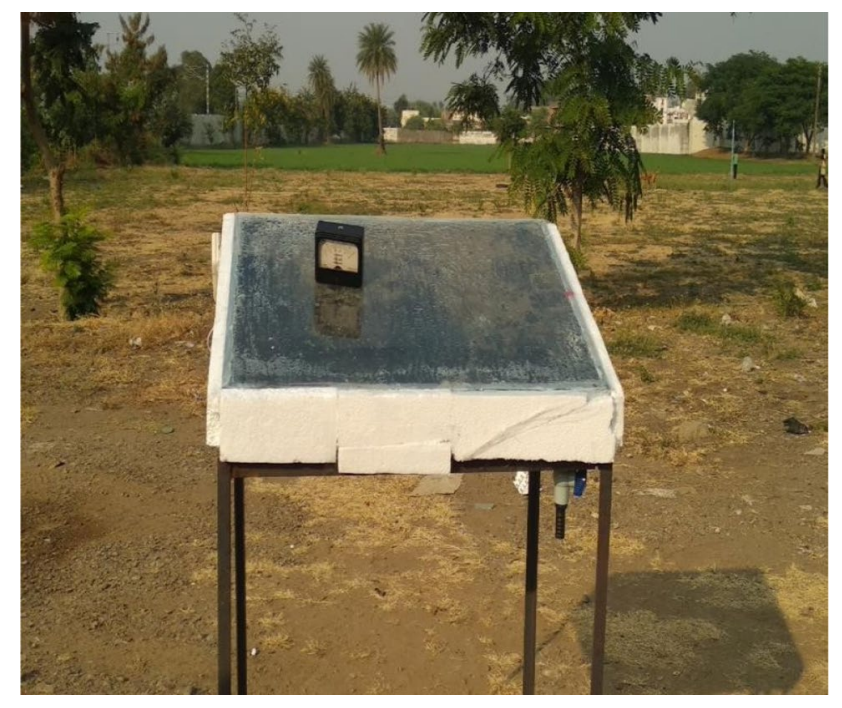

Fig. 2 Fabricated single slope solar still

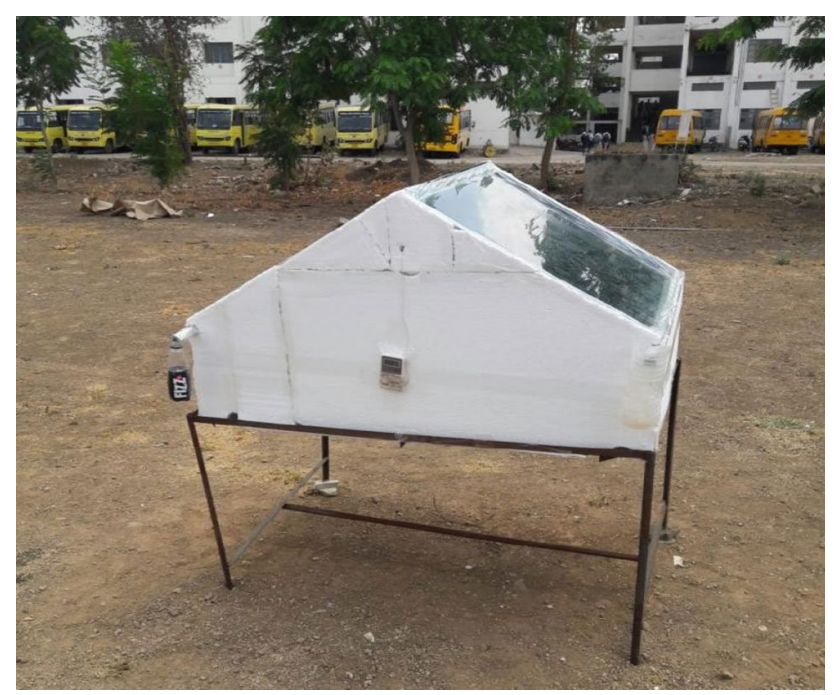

Fig. 3 Fabricated double slope solar still

storing materials and multi wicks by consideration of air velocities and forced convective heat transfer [15-21]. Then exergy concept has been applied to the solar distillation plants [22-26]. Kabeel et al. worked in the climate of the Birkat Elsab City, Monufia, Egypt on two different solar still plants considering composite material and phase changing material, and found the total cost of distilled water with composite material was about $0.0014-0.00163$ US dollars per liter and it was less than the phase changing material by $27 \%$. They also found productivity, energy efficiency and exergy efficiency with composite material about $3.27 \mathrm{~L}$ per square meter, $48.22 \%$ and $3.08 \%$ which were better than the phase changing material by $37.5 \%$,
$38 \%$ and $37 \%$ respectively [23]. Yousef et al. performed comparative analyses on traditional solar still plant, still plant with the phase changing material, still plant with phase changing material-pin fin arrangement, still plant with phase changing material-steel wool fibers, still plant with steel wool fibers and still plant with pin fin arrangement in the basin. They received accumulative freshwater as $3.26,3.572,3.81,3.685,4.08$ and $3.78 \mathrm{~kg} / \mathrm{m}^{2}$ respectively, which were $10 \%, 17 \%, 13 \%, 25 \%$ and $16 \%$ more than traditional solar still plant [24]. Sharshir et al. also analyzed the performance of modified solar still plant which has brackish water with graphite and copper oxide as nano particles with classical or traditional solar still plant. They concluded that the energy efficiencies of the modified solar still with graphite and with copper oxide were $41.18 \%$ and $38.61 \%$ respectively, but for the traditional plant efficiency was only $29.17 \%$. They compared productivity of the modified plant with traditional plant and found productivity enhanced by $41.18 \%$ and $32.35 \%$ with graphite and copper oxide. Exergy efficiency and cost of water production of the modified solar still plant were also confirmed better than traditional plant [26]. Some important outputs related to various solar still plants are also discussed as; Kabeel [27] found $4.0 \mathrm{~L} / \mathrm{m}^{2} /$ day water with concave wick basin pyramidal shaped solar still, Wassouf et al. [28] achieved $1.8 \mathrm{~L} / \mathrm{m}^{2} /$ day water with pyramidal and triangular prism shaped solar still. Rajamanickam and Ragupathy [29], Kumar et al. [30] and Ahsan et al. [31] produced 3.07, 4.2 and $1.6 \mathrm{~L} / \mathrm{m}^{2} /$ day water with double slope, hemispherical shaped and triangular shaped solar still plants respectively. Kumar et al. [32] produced $2.5 \mathrm{~L} / \mathrm{m}^{2} /$ day water with compound parabolic concentrator concentric tubular solar still with water cooling and Velmurugan et al. [33] found $2.77 \mathrm{~L} / \mathrm{m}^{2} /$ day water with fin type solar still. The most important objective of this research work is to obtain clean water from the brackish water, experimentally. In this work, single and double slope solar stills have been fabricated in the workshop for the comparative experimental analyses. Various temperatures and quantities of distilled water through both solar still plants have been found with different solar intensities. Then increments in temperature and quantity of water, thermal efficiencies, rates of exergy at inlet/outlet and exergy efficiencies have been calculated for different time intervals. These comparative outputs have been used to analyses the performance of the solar still plants and identified which plant is doing better, single slope or double slope solar still plant. Dimensions of the fabricated double slope solar still are; length of the basin is $80 \mathrm{~cm}$, width of the basin is $120 \mathrm{~cm}$, height of the basin is $30 \mathrm{~cm}$ and approximate angle of the glass surface is $30^{\circ}-31^{\circ}$ and maximum height of the solar still is $65 \mathrm{~cm}$. Dimensions of the glass used in this experimental work are; $80 \mathrm{~cm}$ length and $70 \mathrm{~cm}$ width. Similarly, 
the dimensions of single slope still are; length, width and height of the basin are 76,56 and $9 \mathrm{~cm}$, the approximate angle of the glass surface is $13^{\circ}-15^{\circ}$, maximum height of the solar still is $22 \mathrm{~cm}$, length and width of the glass are 76 and $58 \mathrm{~cm}$ respectively.

\section{Methodology}

In this experimental research activity, the comparative thermal analyses have been done for single and double slope solar still plants at Sushila Devi Bansal College of Technology, Indore, India. Latitude and Longitude of this location are $22^{\circ} 43^{\prime} 4.51^{\prime \prime} \mathrm{N}$ and $75^{\circ} 49^{\prime} 59.88^{\prime \prime} \mathrm{E}$ respectively. After finding the different temperatures and quantities of distilled water, the thermal efficiencies [1-4] and exergy efficiencies [22-26] have been found in different climatic conditions by adopting the following methodology. First, the thermal efficiency can be defined as the ratio of the amount of heat that is absorbed by water which is present in the basin of the solar still to the solar energy or solar radiation which is received by the rooftop i.e. glass surface of the still [4]. Thermal efficiencies of the single and double slope solar still plants have been found at different time intervals by the following equation [34-38].

$\eta=\left[\left\{\left(m C d T_{w}\right)+\left(m h_{f g}\right)\right\} /\left(\tau_{g} I_{b} R_{B} L W\right)\right] \times 100$

where $\eta$ is the thermal efficiency of the solar still in percentage, $m$ is the mass flow rate of pure water which was obtained by evaporation and condensation processes in $\mathrm{kg} / \mathrm{s}, C$ is the specific heat of water in $\mathrm{J} / \mathrm{kg} \mathrm{K}$ and it is assumed as $4186 \mathrm{~J} / \mathrm{kg} \mathrm{K}, d T_{w}$ is the temperature difference which was recorded due to the solar energy in Kelvin, $I_{b} R_{B}$ is the solar radiation that is available for single and double slope solar still as shown in Fig. 4 in W/m $\mathrm{m}^{2}, L$ and $W$ are the length and width of the solar still in meters. $a_{g}, \rho_{g}$ and $\tau_{g}$ are absorptivity, reflectivity and transmissivity of the glass and these terms can be defined as; the absorptivity is the ratio of absorbed radiation to the total incident radiation, the reflectivity is the ratio of reflected radiation to the total incident radiation and the transmissivity of the glass is the ratio of transmitted radiation to the total incident radiation respectively. For this experimental research work, these constants have been taken as-combined absorptivityreflectivity 0.2 and transmissivity 0.8 . The maximum useful work that received from any thermodynamic system if the system approaches to thermodynamic equilibrium state with the surroundings is called available energy, i.e. exergy of the system [39-42]. In this research work exergy inputs, exergy outputs and exergy efficiencies for single and double slope solar stills have been calculated by the following equations [22-26, 34-37].

$$
\begin{gathered}
\Psi_{\text {in }}=I_{b} R_{B} L W\left\{1-\left(4 T_{0} / 3 T_{s}\right)+(1 / 3)\left(T_{0} / T_{s}\right)^{4}\right\} \\
\Psi_{\text {out }}=\left\{\left(m C d T_{w}\right)+\left(m h_{f g}\right)\right\}\left[1-\left(T_{0} / T_{w}\right)\right] \\
\eta_{\psi}=\left\{\left\{\left(m C d T_{w}\right)+\left(m h_{f g}\right)\right\}\left[1-\left(T_{0} / T_{w}\right)\right]\right\} / \\
\left\{I_{b} R_{B} L W\left\{1-\left(4 T_{0} / 3 T_{s}\right)+(1 / 3)\left(T_{0} / T_{s}\right)^{4}\right\}\right\}
\end{gathered}
$$

where $\psi_{\text {in }}$ and $\psi_{\text {out }}$ are the rates of exergy at inlet and outlet for single and double slope solar stills in Watt, $T_{0}, T_{w}$ and $T_{s}$ are the ambient, water and Sun's surface temperatures. Surface temperature of the Sun has been taken as $5800 \mathrm{~K}$ $[34-37,43]$.

\section{Results and discussion}

Many researchers have done work on distillation by many ways to improve the performance of the still plants, but in this experimental work single and double slope solar distillation plants have been fabricated for comparative analyses at different conditions i.e. solar intensities and time intervals. These analyses have been done to recognize which solar still plant is performing well (single slope or double slope solar still plant) and those operating conditions/time intervals have also been identified. Various experiments have been performed on single and double slope solar stills at different time intervals. Ismail [44] designed a hemispherical dome shaped transparent plastic cover still plant (size $0.5 \mathrm{~m}^{2}$ ) and observed when the depth of the water in the basin increases (i.e. 50\%) then the efficiency of the still plant decreases (i.e. 8\%). He also worked on still plant with different wind speeds and found when the speed increases distillation rate also increases. Varol and Yazar [45] fabricated conventional and novel (glass cover coated with a thin layer of $\mathrm{SnO}_{2}$ ) solar still plants which covered by low $\mathrm{Fe}_{2} \mathrm{O}_{3}$ composed glasses of $4 \mathrm{~mm}$ thickness and tilted at an angle of $15^{\circ}$ with the horizontal. They compared the performance of both still plants and found $3.695 \mathrm{~L} / \mathrm{m}^{2}$ distilled water between $7 \mathrm{AM}$ and $9 \mathrm{PM}$ and $3.050 \mathrm{~L} / \mathrm{m}^{2}$ distilled water between $9 \mathrm{PM}$ and $7 \mathrm{AM}$. They concluded that the novel (or modified) still plant gives 3.26 times higher overall efficiency than conventional still plant. Minasian and Al-Karaghouli [46] worked on comparative analyses of basin and wick basin type solar distillation plants and found $85 \%$ more annual production from the wick basin type plant. Sahoo et al. [47] removed $92-96 \%$ of fluoride from the drinking water and they also investigated efficiencies of the solar still plant which were evaluated as $8.59 \%$ and $8.48 \%$ with and without insulation of the plant. Soda et al. [48] analyzed the performance of multi wick solar still plant where jute 
Fig. 4 Solar radiation available for $\mathbf{a}$ double slope and $\mathbf{b}$ single slope solar stills

\section{(a) Solar radiation available for double slop solar still}

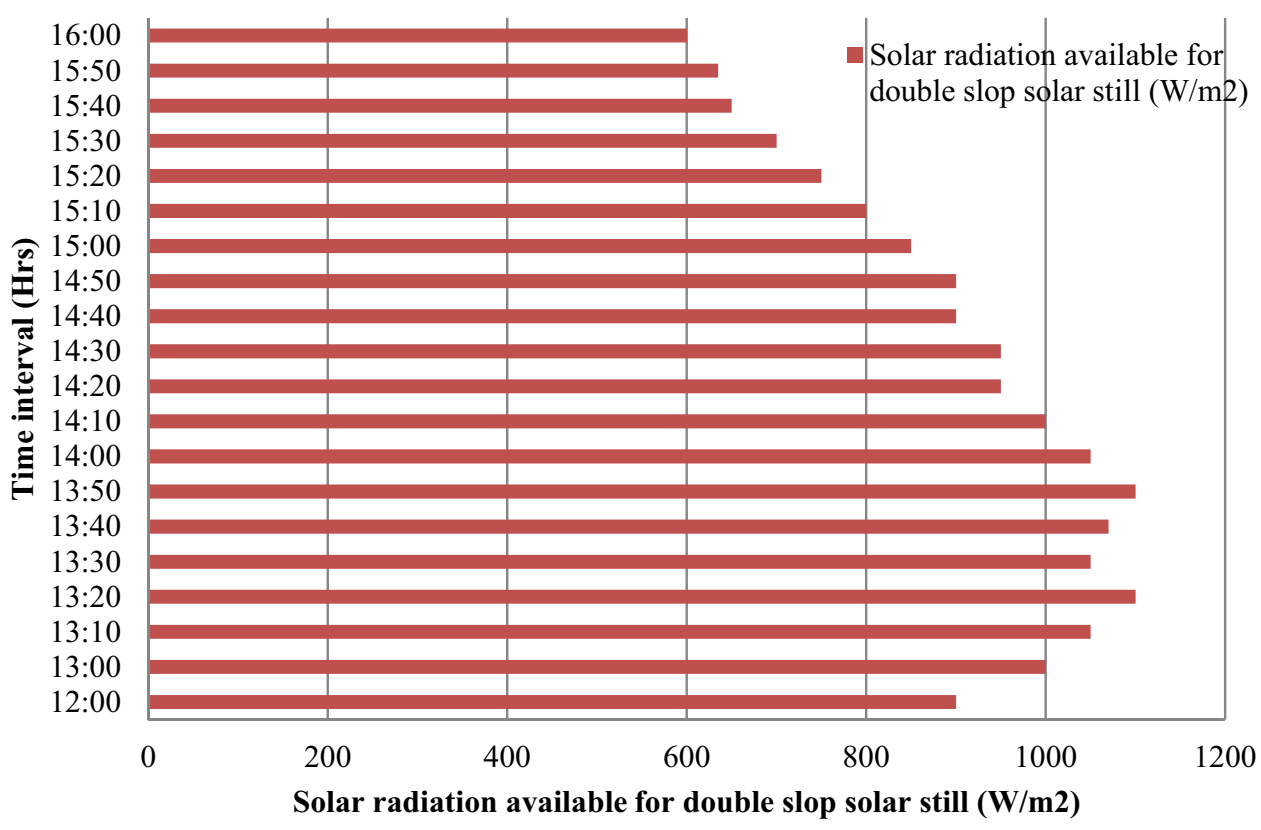

(b) Solar radiation available for single slop solar still

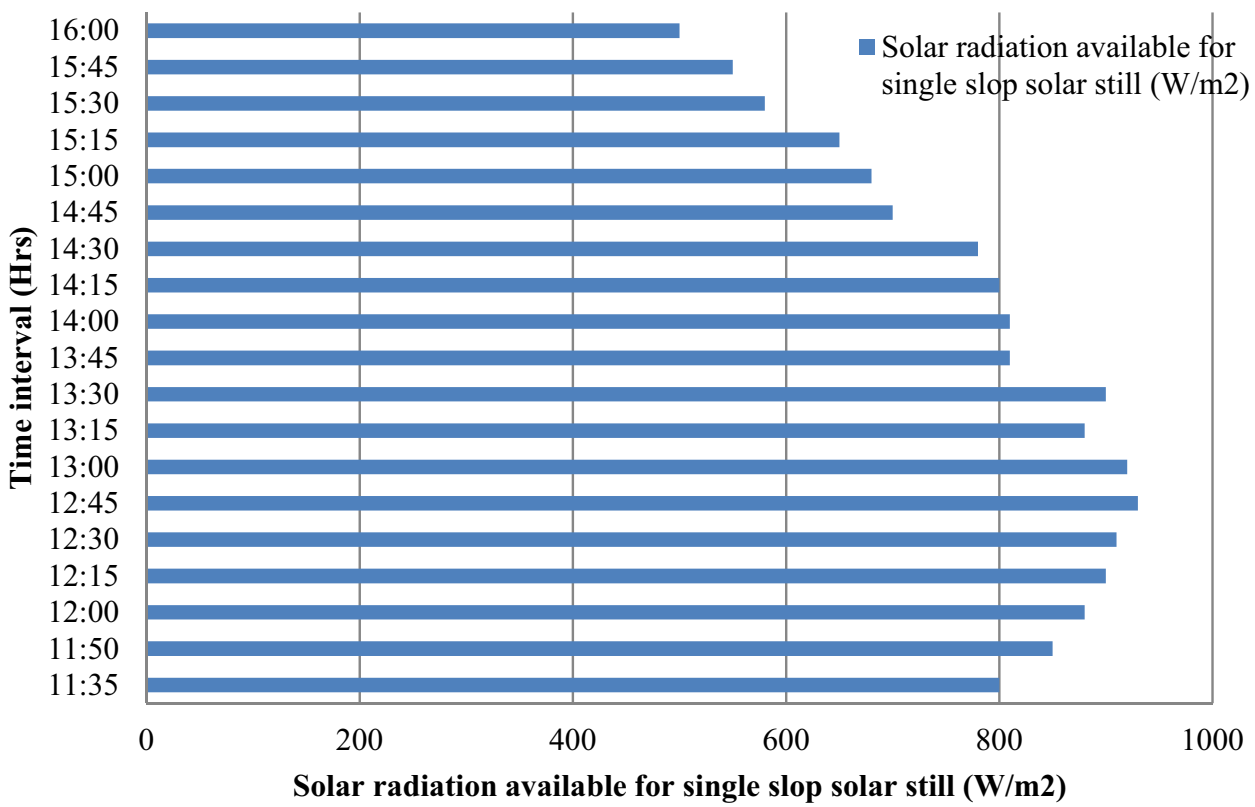

clothes were used as wick material. After analyses they found $2.5 \mathrm{~L} / \mathrm{m}^{2}$ distilled water daily, and overall efficiency of the plant about $34 \%$ with multi wick. Sakthivel et al. [49] used jute clothes as an energy storage medium and placed vertically in the single basin solar still plant and they analyzed this arrangement with conventional solar still and found $8 \%$ better efficiency than conventional plant. Cappelletti [50] made two plastic basins with different inclination angles $\left(45^{\circ}\right.$ and $\left.35^{\circ}\right)$ and recorded $16 \%$ efficiency of the still plant with 1.7 to $1.8 \mathrm{~L} / \mathrm{m}^{2}$ distilled water in a day. Al-Karaghouli et al. [51] investigated the performance of fabricated single and double slope double decker solar still plants. They recorded $3.91 \mathrm{~L} / \mathrm{m}^{2}$ and $2.45 \mathrm{~L} / \mathrm{m}^{2}$ distilled water with $31.8 \%$ and $43.8 \%$ plant efficiencies from single and double basin with insulation respectively. Al-Hayek and Badran [52] tested solar still with reflecting mirror and conventional still plants and obtained 3 to $5.5 \mathrm{~L} / \mathrm{m}^{2}$ distilled water. Nijmeh et al. [53] fabricated single basin solar 
still insulated on the bottom and sides with $10 \mathrm{~cm}$ thick Styrofoam and used different dissolved salts; potassium permanganate, potassium dichromate and violet dye and charcoal. After investigations, they found $5.7 \mathrm{~L} / \mathrm{m}^{2}, 5.5 \mathrm{~L} /$ $\mathrm{m}^{2}$ and $5.3 \mathrm{~L} / \mathrm{m}^{2}$ distilled water with $17.2 \%, 26 \%$ and $19 \%$ plant efficiencies for potassium permanganate, potassium dichromate and for charcoal respectively. Bassam et al. [54] investigated the effects of size/volume of sponge, water depth, use of black coal and black still cube on the performance of still plant. They found that the production rate increases from 18 to $273 \%$ with sponge. Flendrig et al. [55] fabricated solar water purifier with $3 \mathrm{~mm}$ thick black high density polyethylene sheet and corrugated surface at the bottom of the still basin to create better insulation. After experiments, they found $3 \mathrm{~L} / \mathrm{m}^{2}$ distilled water with $39 \%$ overall efficiency of the plant. Kumar and Bai [56] studied the performance of solar still plant with enhanced condensation method and found $30 \%$ of the plant efficiency. In this research work, experimental readings for the double slope solar still from 12:00 to 16:00 PM have been shown through Table 1 whereas the readings for single slope still from 11:35 AM to 16:00 PM have been revealed in Table 2 . Changes in temperature and quantity of water have been presented in Figs. 5 and 6 with single and double slope solar stills. Better increments in the quantity of distilled water have been obtained at peak hours between 14:30 and 14:50 PM. It has also been shown in the Fig. 5 that the increment in the quantity of distilled water is gradually increasing up to the peak hour and then gradually decreasing. Thermal efficiencies of single and double solar stills have been shown in Fig. 7 at different time intervals and this figure indicates the maximum efficiency of the fabricated solar distillation plant recorded at peak hours i.e. from 14:30 to 14:50 PM by experiments. Rates of exergy at inlet/outlet and exergy efficiencies for single and double slope solar stills have been estimated and represented in Figs. 8,9 and 10 respectively. Better experimental outputs from both still plants have been received between 14:30 and 14:50 PM by exergy analyses.

In this research work percentage increments/decrements in-temperature, distilled water quantity, thermal efficiency, rates of exergy at inlet/outlet and exergy efficiency have also been found for both solar stills as in Tables 3 and 4. Maximum and minimum available solar radiations for the single slope solar still are 930 and $500 \mathrm{~W} / / \mathrm{m}^{2}$ at $12: 30$ and $16: 00 \mathrm{PM}$, and for double slope solar still are 1100 and $600 \mathrm{~W} / \mathrm{m}^{2}$ at 13:20 and 16:00 PM receptively as in Fig. 4. Maximum and minimum thermal efficiencies for single slope solar still have been observed as $47.260 \%$ and $11.860 \%$. Maximum and minimum rates of exergy at inlet have been calculated as $368.246 \mathrm{~W}$ and 198.079 W. Maximum and minimum rates of exergy at outlet have been determined as $9.906 \mathrm{~W}$ and $1.588 \mathrm{~W}$. Maximum and minimum exergy efficiencies have also been
Table 1 Experimental readings taken from double slope solar still at different time intervals

\begin{tabular}{llllll}
\hline Sr. no. & Time $(\mathrm{PM})$ & $\begin{array}{l}\text { Temperature of } \\
\text { water }\left({ }^{\circ} \mathrm{C}\right)\end{array}$ & $\begin{array}{l}\text { Solar radiation } \\
\left(\mathrm{W} / \mathrm{m}^{2}\right)\end{array}$ & $\begin{array}{l}\text { Atmospheric tem- } \\
\text { perature }\left({ }^{\circ} \mathrm{C}\right)\end{array}$ & $\begin{array}{l}\text { Amount of } \\
\text { distilled water } \\
(\mathrm{L})\end{array}$ \\
\hline 1 & $12: 00$ & 43 & 900 & 30 & 00 \\
2 & $13: 00$ & 44 & 1000 & 33 & 0.005 \\
3 & $13: 10$ & 45.3 & 1050 & 35 & 0.009 \\
4 & $13: 20$ & 45.9 & 1100 & 34 & 0.015 \\
5 & $13: 30$ & 46 & 1050 & 33 & 0.020 \\
6 & $13: 40$ & 47.8 & 1070 & 35 & 0.030 \\
7 & $13: 50$ & 47.9 & 1100 & 34 & 0.045 \\
8 & $14: 00$ & 48.4 & 1050 & 32 & 0.060 \\
9 & $14: 10$ & 48.9 & 1000 & 31 & 0.080 \\
10 & $14: 20$ & 48.4 & 950 & 30 & 0.100 \\
11 & $14: 30$ & 48 & 950 & 32 & 0.200 \\
12 & $14: 40$ & 47.9 & 900 & 33 & 0.300 \\
13 & $14: 50$ & 47.7 & 900 & 32 & 0.400 \\
14 & $15: 00$ & 46.9 & 850 & 30 & 0.450 \\
15 & $15: 10$ & 46 & 800 & 30 & 0.500 \\
16 & $15: 20$ & 45.8 & 750 & 29 & 0.550 \\
17 & $15: 30$ & 44.9 & 700 & 29 & 0.600 \\
18 & $15: 40$ & 43 & 650 & 28 & 0.650 \\
19 & $15: 50$ & 42.6 & 635 & 28 & 0.675 \\
20 & $16: 00$ & 42 & 600 & 28 & 0.700 \\
\hline
\end{tabular}


Table 2 Experimental readings taken from single slope solar still at different time intervals

\begin{tabular}{llllll}
\hline Sr. no. & Time & $\begin{array}{l}\text { Temperature of } \\
\text { water }\left({ }^{\circ} \mathrm{C}\right)\end{array}$ & $\begin{array}{l}\text { Solar radiation } \\
\left(\mathrm{W} / \mathrm{m}^{2}\right)\end{array}$ & $\begin{array}{l}\text { Atmospheric tem- } \\
\text { perature }\left({ }^{\circ} \mathrm{C}\right)\end{array}$ & $\begin{array}{l}\text { Amount of } \\
\text { distilled water } \\
(\mathrm{L})\end{array}$ \\
\hline 1 & $11: 35 \mathrm{AM}$ & 48.9 & 800 & 28 & 0.010 \\
2 & $11: 50 \mathrm{AM}$ & 54.4 & 850 & 29 & 0.040 \\
3 & $12: 00 \mathrm{PM}$ & 56.8 & 880 & 30 & 0.055 \\
4 & $12: 15 \mathrm{PM}$ & 59.2 & 900 & 30 & 0.075 \\
5 & $12: 30 \mathrm{PM}$ & 59.9 & 910 & 30 & 0.085 \\
6 & $12: 45 \mathrm{PM}$ & 59 & 930 & 30 & 0.095 \\
7 & $13: 00 \mathrm{PM}$ & 57.9 & 920 & 28 & 0.115 \\
8 & $13: 15 \mathrm{PM}$ & 59.6 & 880 & 28 & 0.130 \\
9 & $13: 30 \mathrm{PM}$ & 60.6 & 900 & 29 & 0.140 \\
10 & $13: 45 \mathrm{PM}$ & 59.3 & 810 & 29 & 0.150 \\
11 & $14: 00 \mathrm{PM}$ & 59.8 & 810 & 30 & 0.165 \\
12 & $14: 15 \mathrm{PM}$ & 58.9 & 800 & 30 & 0.175 \\
13 & $14: 30 \mathrm{PM}$ & 57.05 & 780 & 28 & 0.195 \\
14 & $14: 45 \mathrm{PM}$ & 56.03 & 700 & 28 & 0.225 \\
15 & $15: 00 \mathrm{PM}$ & 53.4 & 680 & 28 & 0.240 \\
16 & $15: 15 \mathrm{PM}$ & 50.3 & 650 & 28 & 0.255 \\
17 & $15: 30 \mathrm{PM}$ & 47.1 & 580 & 29 & 0.275 \\
18 & $15: 45 \mathrm{PM}$ & 45.5 & 550 & 28 & 0.295 \\
19 & $16: 00 \mathrm{PM}$ & 40 & 500 & 28 & 0.310 \\
\hline
\end{tabular}

estimated as $3.390 \%$ and $0.802 \%$ as shown in Figs. 7, 8, 9 and 10 respectively at different time intervals. Similarly, maximum and minimum thermal efficiencies for double slope solar still have been calculated as 46.639 and $1.603 \%$, rates of exergy at inlet have been found as 1145.077 and $607 \mathrm{~W}$, rates of exergy at outlet have been estimated as 18.471 and $0.523 \mathrm{~W}$, and exergy efficiencies have been calculated as 1.95 and $0.048 \%$ at various time intervals as in Figs. 7, 8, 9 and 10 respectively. All these analyses have been used for the comparative analyses of single and double slope solar still plants.

Maximum percentage increments in the quantity of distilled water were recorded for single and double slope solar still plants so maximum increments in the thermal and exergy efficiencies have been obtained at peak hours between 14:15 and 14:30 PM. Maximum thermal efficiencies for single and double slope still plants have been achieved after 14:40 PM. Maximum rates of inlet and outlet exergy have been found between 13:00 and 14:30 PM respectively for both solar stills and between this duration solar intensities were found better. Best exergy efficiencies for single and double slope still plants have also been examined between 14:30 and 14:50 PM experimentally because the still plants were preheated and found better intensity.

Important results of this experimental work are discussed as; Maximum thermal i.e. $46.64 \%$ and exergy i.e. $1.95 \%$ efficiencies for double slope solar still have been obtained at 14:50 PM. The maximum increments in thermal i.e. $400.09 \%$ and exergy i.e. $336.12 \%$ efficiencies have been found at 14:30 PM but minimum thermal i.e. $1.603 \%$ and exergy i.e. $0.047 \%$ efficiencies have been obtained at 13:10 PM. Maximum increment in the temperature of water i.e. $1.8^{\circ} \mathrm{C}$ has been achieved at 13:40 PM but maximum increment in the quantity of water i.e. $0.1 \mathrm{~L}$ has been observed between 14:30 and 14:50 PM. Maximum i.e. $1145.076 \mathrm{~W}$ and minimum i.e. $625.513 \mathrm{~W}$ rates of inlet exergy have been found at 13:20 PM and 16:00 PM respectively. Maximum i.e. $18.47 \mathrm{~W}$ and minimum i.e. $0.523 \mathrm{~W}$ rates of outlet exergy have been found at 14:30 and 13:10 PM respectively. Maximum and minimum percentage changes in temperature, quantity of water, thermal efficiency, rates of inlet/ outlet exergy and exergy efficiency have been obtained as $1700-0 \%, 400-0 \%, 400.092-0.018 \%, 7.119-0.024 \%$, $335.906-0.375 \%$ and $336.121-0.336 \%$ respectively at 13:40-14:10 PM, 14:30-15:10 PM, 14:30-14:50 PM, 15:40-14:50 PM, 14:30-14:20 PM and 14:30-15:10 PM. After comparative analyses of these experimental outputs, 14:50 PM time interval has been recorded better for double slope solar still where solar intensity was $900 \mathrm{~W} /$ $\mathrm{m}^{2}$ and thermal/exergy efficiencies were the best with the highest increment in the quantity of distilled water. For double slope solar still, 14:30 PM time interval can also be considered where the percentage increments in quantity of water, thermal efficiency, outlet exergy and 
Fig. 5 a Change in temperature and $\mathbf{b}$ increment in quantity of water with double slope solar still (a) Change in temperature of water $\left({ }^{\circ} \mathrm{C}\right)$

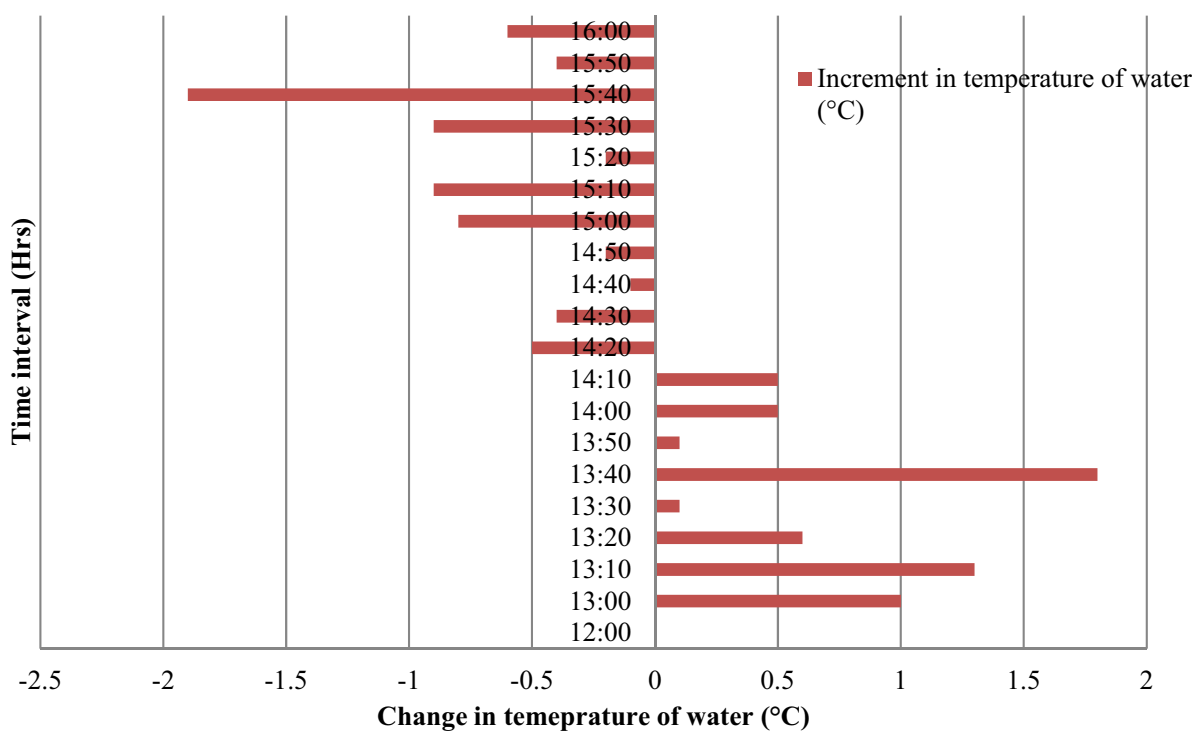

(b) Increment in quantity of water (Liters)

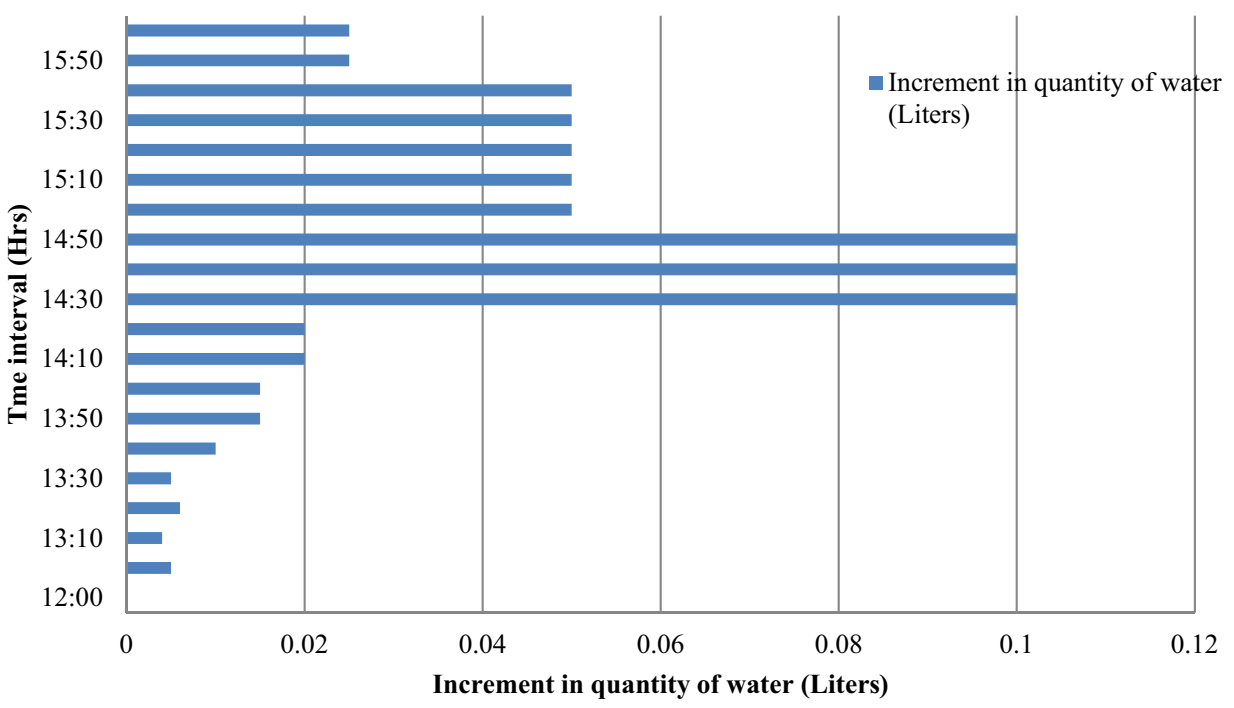

exergy efficiency were found highest which are good conditions for the best performance of a solar still. It has also been examined that 13:10 PM time interval is not good for still because it was showing poor performance of solar still in terms of thermal and exergy efficiencies. Experimental work with single slope solar still can also be concluded as; Maximum thermal i.e. $47.259 \%$ and exergy i.e. $3.389 \%$ efficiencies have been achieved at 14:45 PM. Maximum increments in the quantity of distilled water, outlet exergy and exergy efficiency i.e. $100,106.161$ and $108.299 \%$ have been found at
13:00 PM respectively. But minimum inlet exergy, outlet exergy and exergy efficiency i.e. $198.079 \mathrm{~W}, 1.587 \mathrm{~W}$ and $0.801 \%$ have been obtained at 16:00 PM. Maximum increment in the quantity of distilled water i.e. $0.03 \mathrm{~L}$ has been recorded at 14:45 PM. Maximum i.e. 368.245 W and minimum i.e. $198.079 \mathrm{~W}$ rates of inlet exergy have been received at 12:45 and 16:00 PM respectively. Maximum i.e. $9.906 \mathrm{~W}$ and minimum i.e. $1.587 \mathrm{~W}$ rates of outlet exergy have been found at 11:50 and 16:00 PM respectively. Maximum and minimum percentage changes in the temperature of water, thermal efficiency, rates of 
Fig. 6 a Change in temperature and $\mathbf{b}$ interment quantity of water with single slope solar still (a) Change in temperature of water $\left({ }^{\circ} \mathrm{C}\right)$

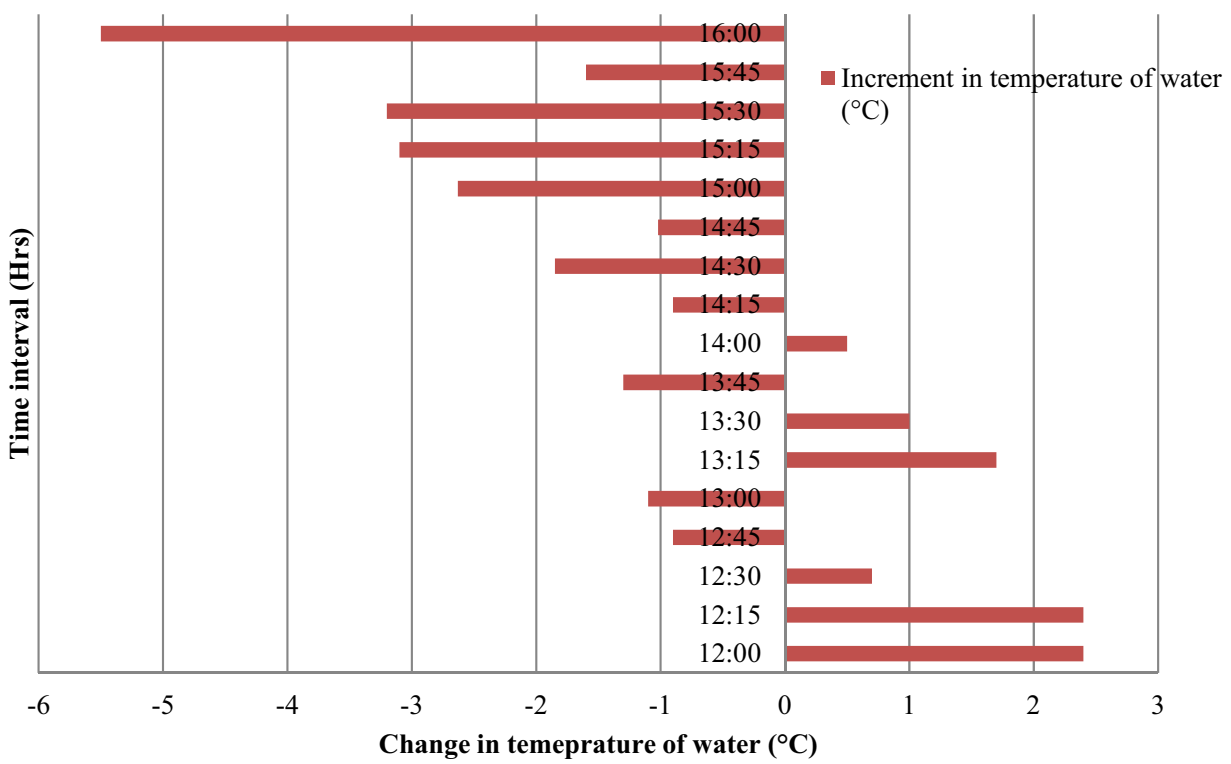

(b) Increment in quantity of water (Liters)

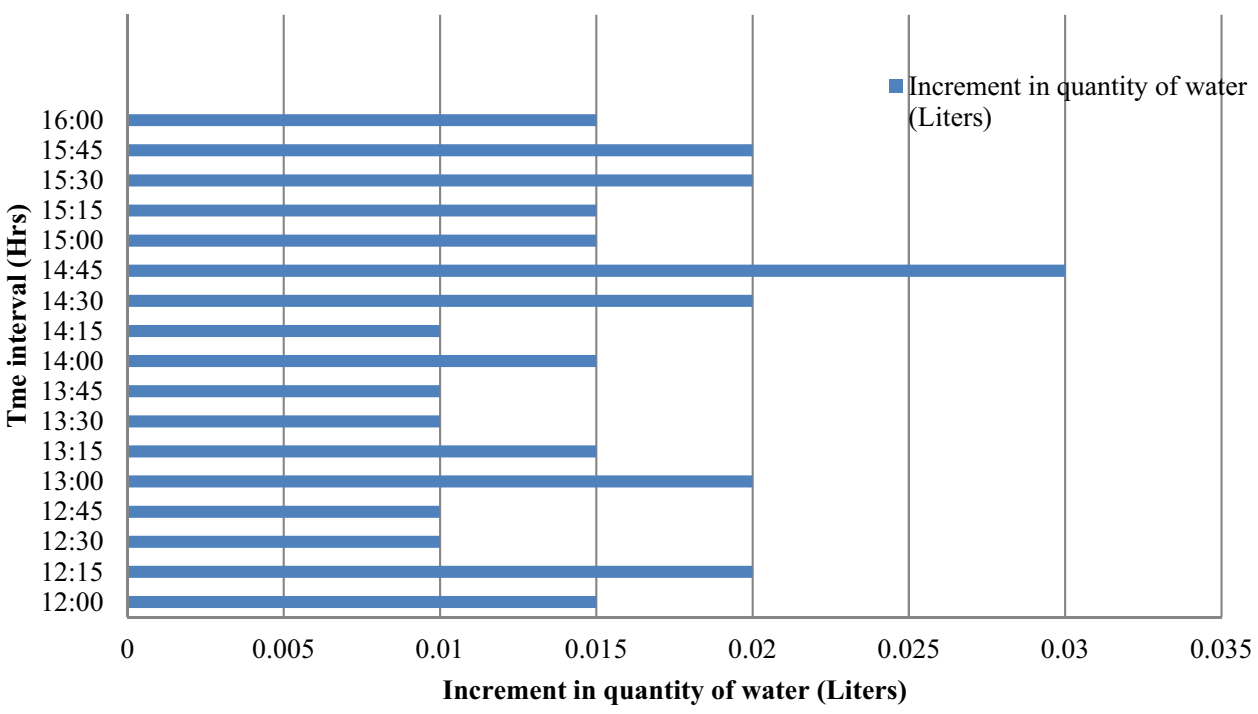

inlet/outlet exergy and exergy efficiency for single slope have been obtained as $280-3.225 \%, 104.766-2.44 \%$, $10.791-0.024 \%, 106.161-2.702 \%$ and $108.299-2.129 \%$ respectively at 14:15-15:30 PM, 14:30-12:45 PM, 15:30-14:00 PM, 13:00-15:45 PM and 13:00-13:45 PM.

\section{Conclusion}

The main aim of this experimental attempt is to get pure water from the available brackish/impure water. At the end of the experiment, $0.7 \mathrm{~L}$ pure water has been collected. Single and double slope solar stills have been fabricated in the workshop, and increments in the temperature/quantity of water, thermal efficiencies, rates of exergy at inlet/outlet and exergy efficiencies have been investigated at different solar intensities. Percentage increments and decrements have also been found for various performance analysing parameters. Comparative studies have been done for both solar stills with various operating conditions to find which solar still plant is performing better/well. For single slope solar still, 14:45 PM time interval has been found better where solar intensity was $700 \mathrm{~W} / \mathrm{m}^{2}$ and thermal/exergy efficiencies were the 
Fig. 7 Thermal efficiencies for a double and $\mathbf{b}$ single slope solar stills (a) Thermal efficiency for double slop solar still

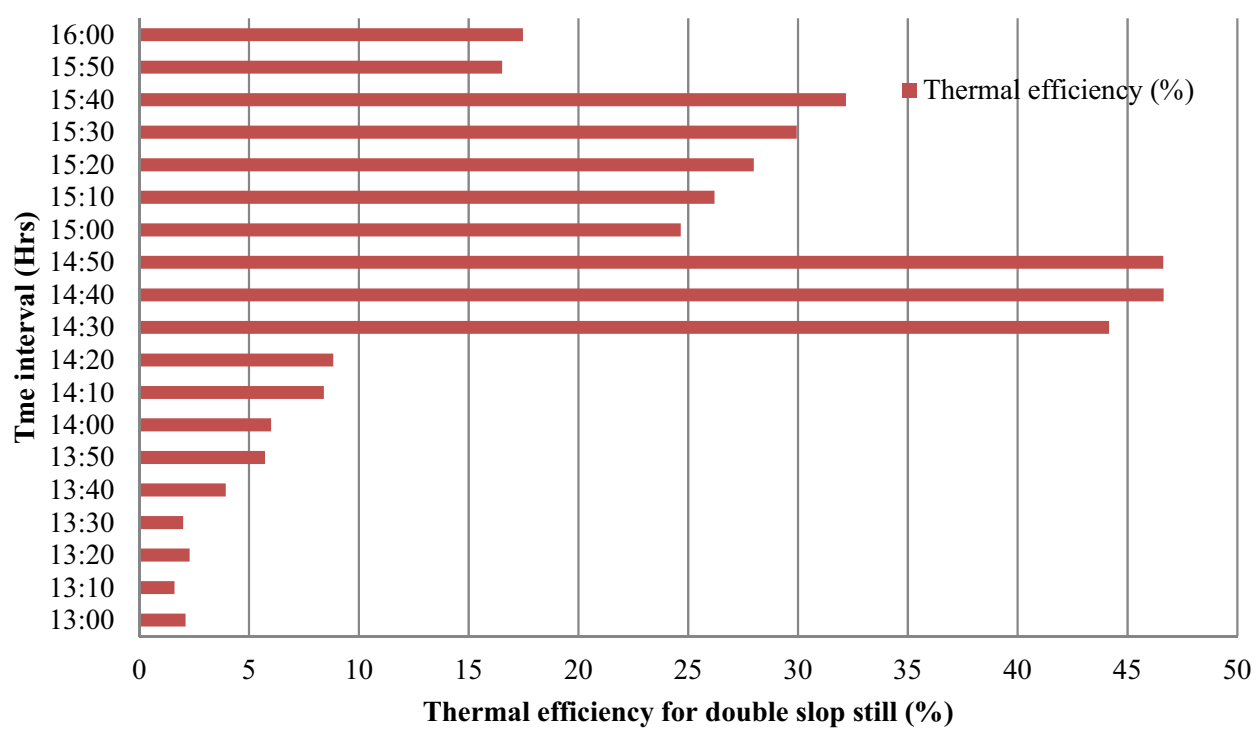

(b) Thermal efficiency for single slop solar still

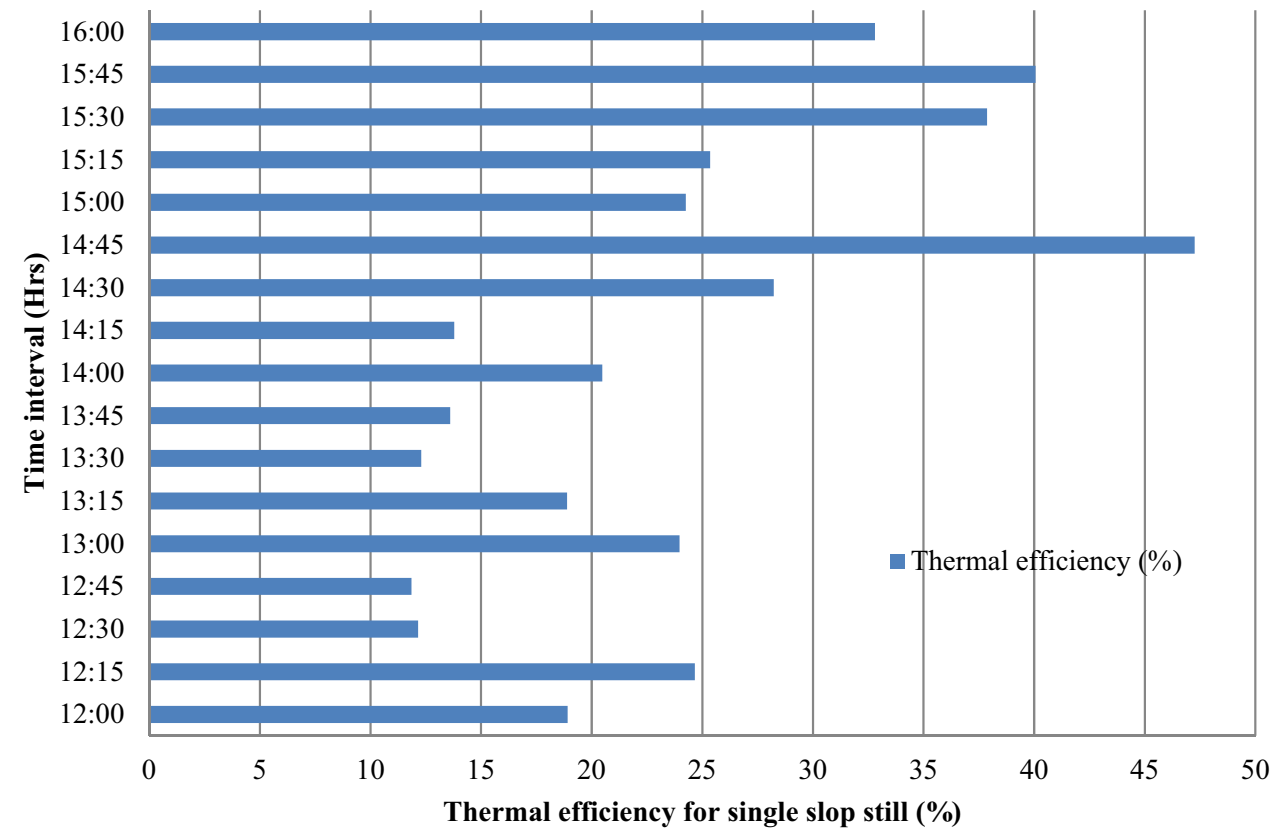

most excellent with maximum growth in the quantity of distilled water. After comparative analyses it has been observed that 14:30 to 14:50 PM time duration gives better performance for the distillation of water through solar still plants as the distillation is the cumulative effect of solar intensity which incidents on the solar distillation plants. It has also been observed in this experimental work that the single slope solar distillation plant gives better thermal and exergy efficiencies. Because the maximum increment in the quantity of distilled water has been recorded at comparatively poor solar intensity. Furthermore, maximum increment also depends on the position of the glass and incident solar radiation for single slope solar still. In future, different wick materials, 
Fig. 8 Rates of exergy at inlet for $\mathbf{a}$ double and $\mathbf{b}$ single slope solar stills (a) Rates of exergy at inlet for double slop solar still

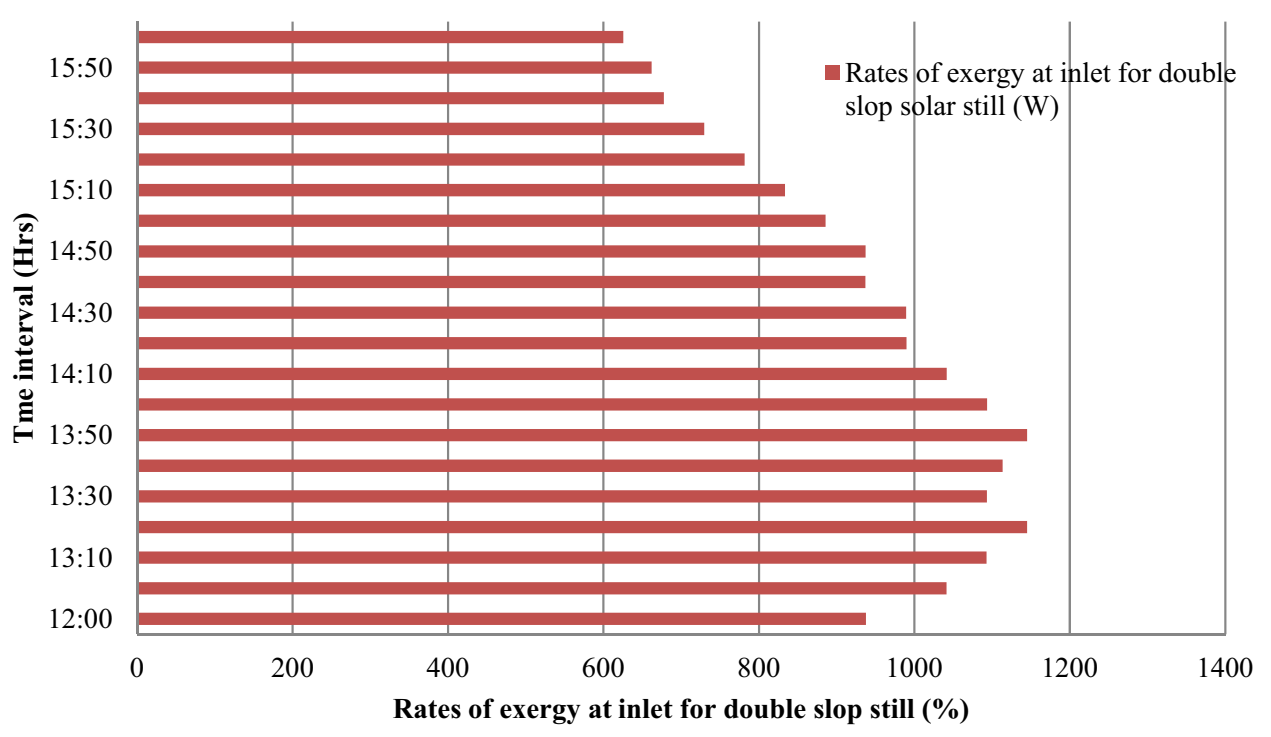

(b) Rates of exergy at inlet for single slop solar still

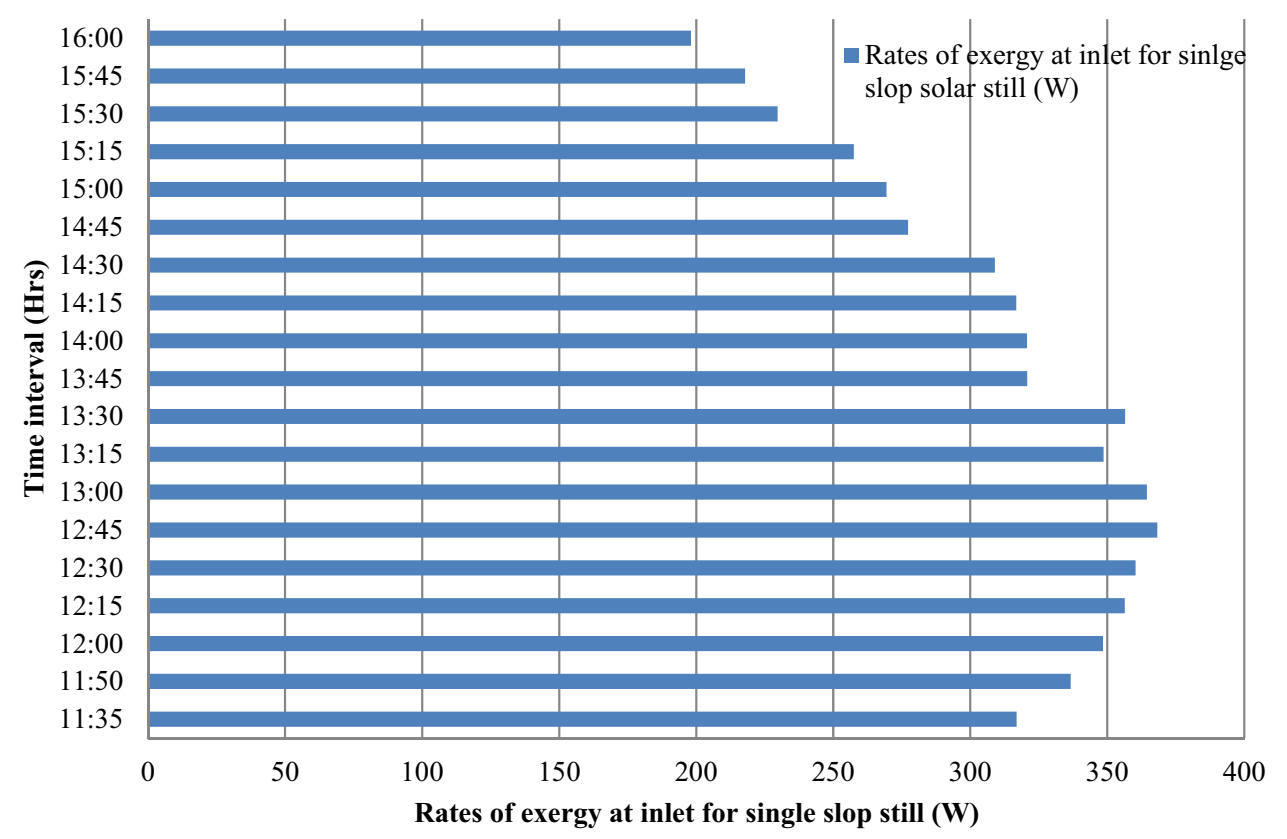


Fig. 9 Rates of exergy at outlet for $\mathbf{a}$ double and $\mathbf{b}$ single slope solar stills (a) Rates of exergy at outlet for double slop solar still

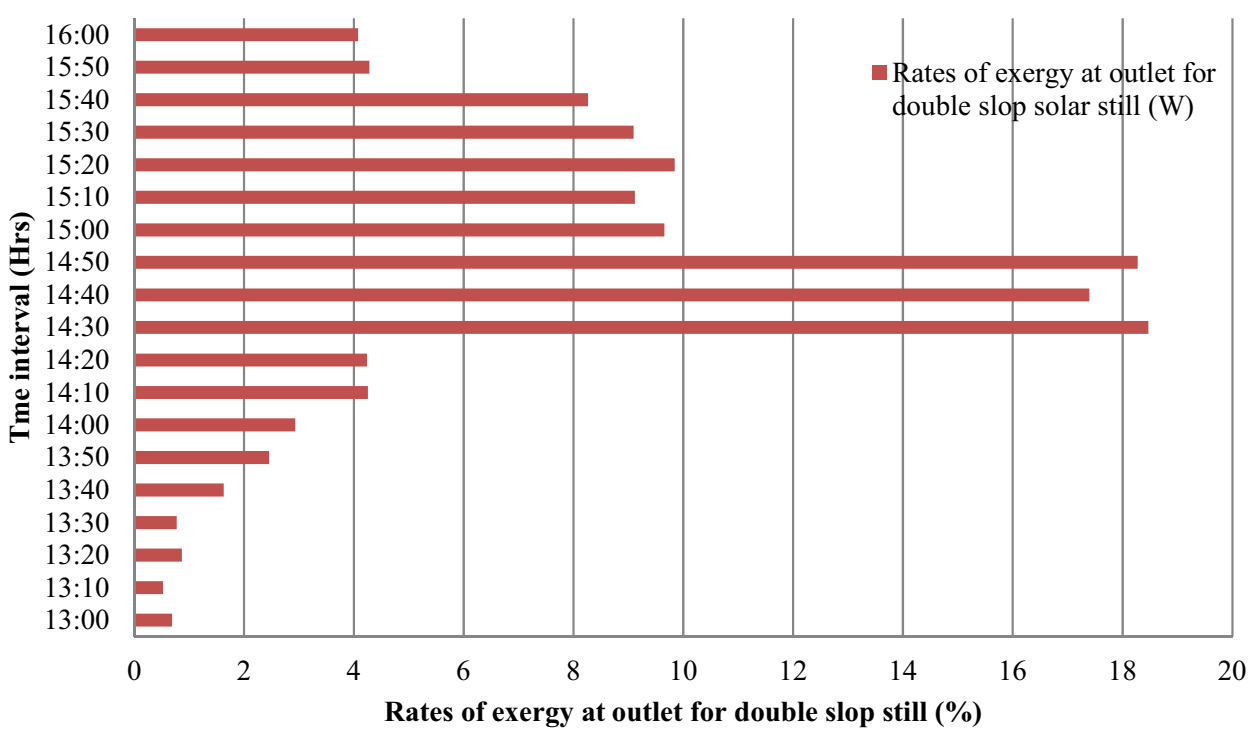

(b) Rates of exergy at outlet for single slop solar still

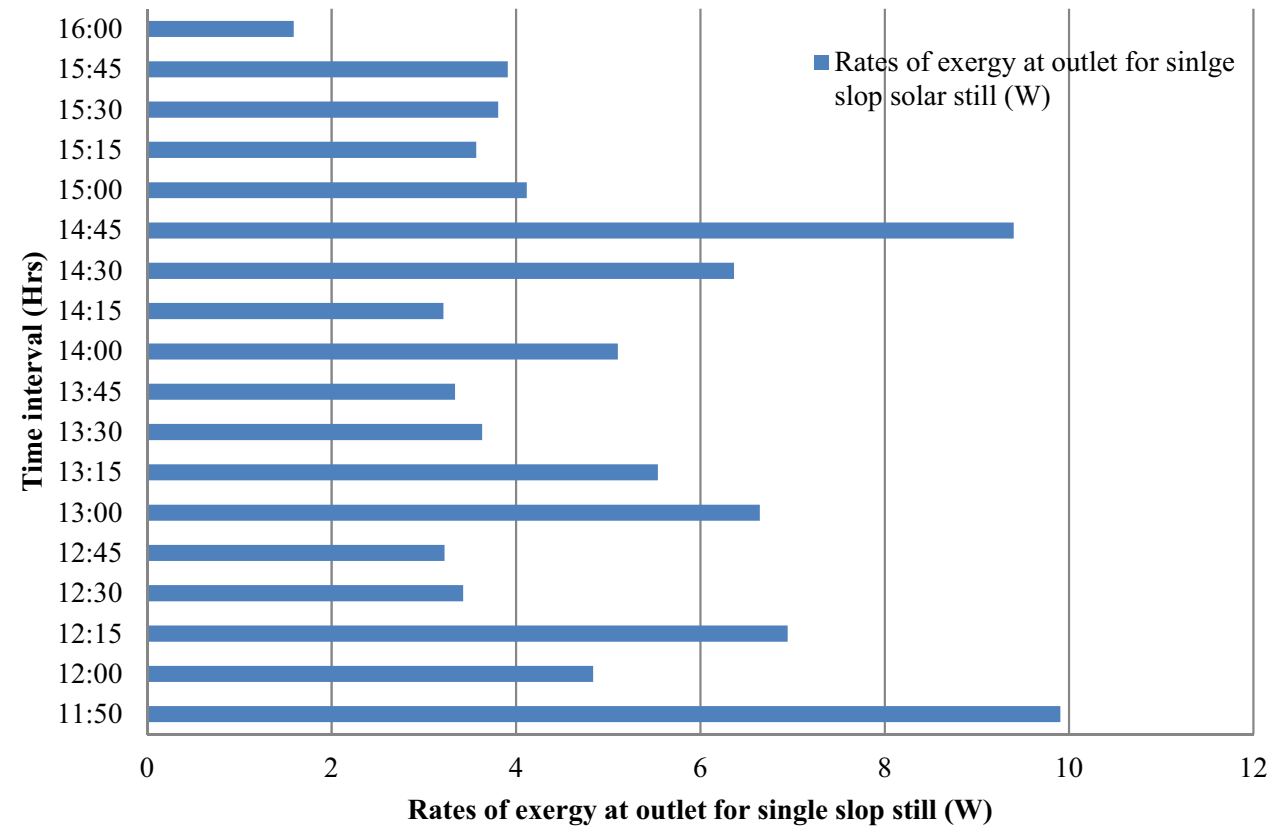


Fig. 10 Exergy efficiencies for a double and $\mathbf{b}$ single slope solar stills (a) Exergy efficiency for double slop solar still

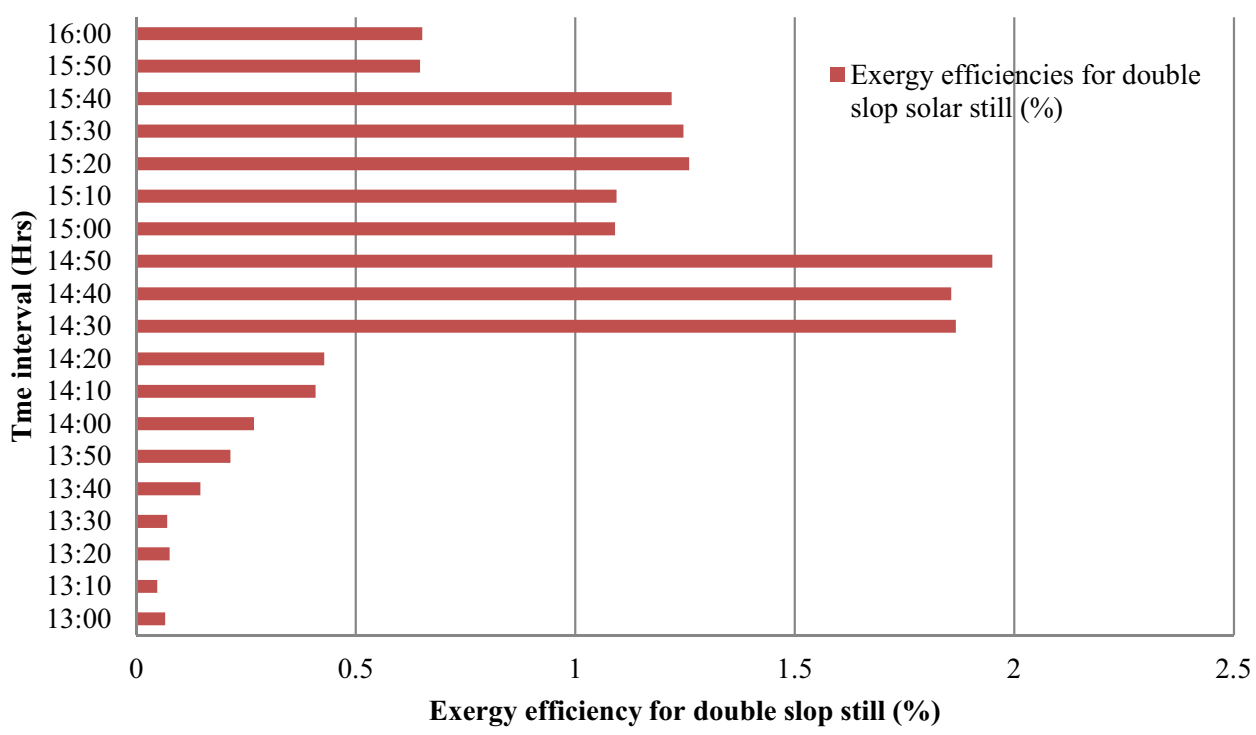

(b) Exergy efficiency for single slop solar still

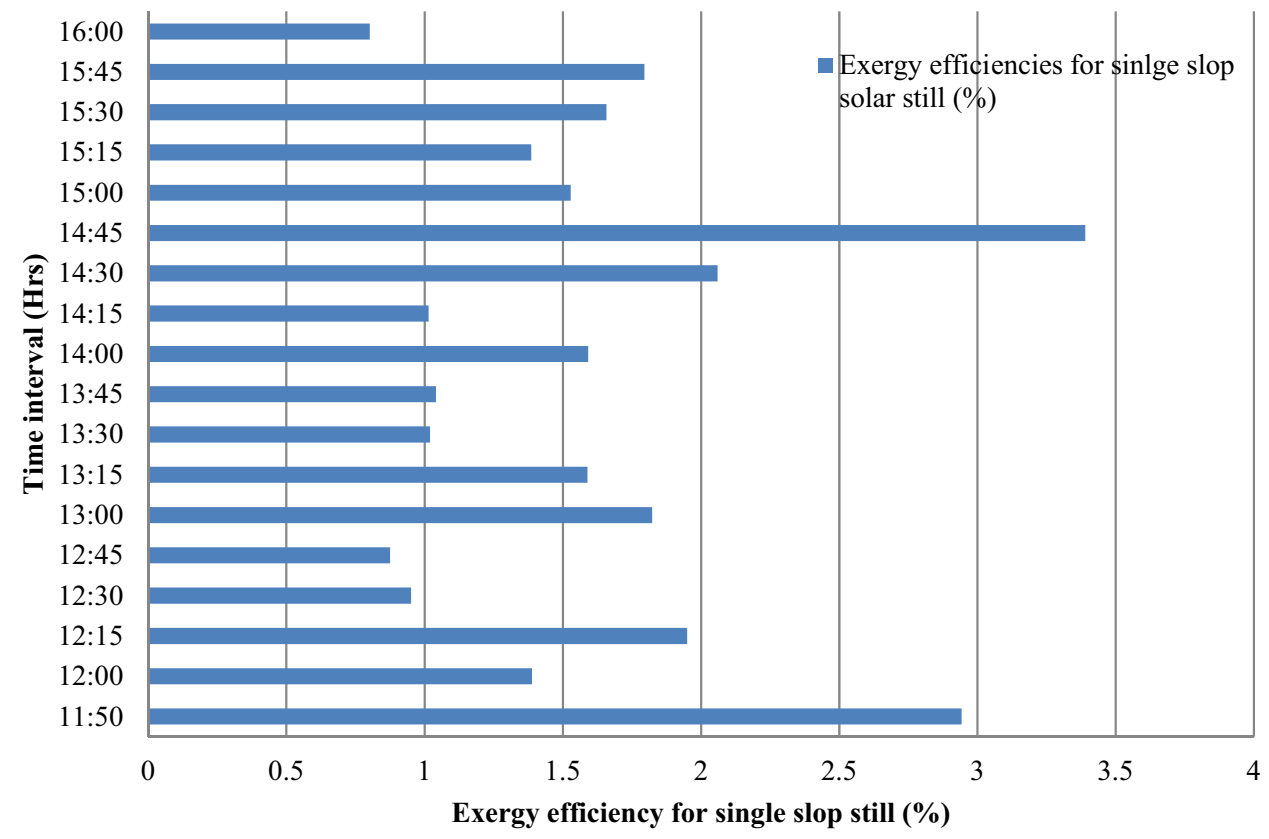


Table 3 Percentage changes in various parameters at various time durations for double slope solar still

\begin{tabular}{|c|c|c|c|c|c|c|c|}
\hline Sr. no. & Time durations & $\begin{array}{l}\text { Percentage } \\
\text { change in } \\
\text { increment in } \\
\text { temperature of } \\
\text { water (\%) }\end{array}$ & $\begin{array}{l}\text { Percentage } \\
\text { change in incre- } \\
\text { ment in quantity } \\
\text { of water (\%) }\end{array}$ & $\begin{array}{l}\text { Percentage } \\
\text { change in ther- } \\
\text { mal efficiency } \\
(\%)\end{array}$ & $\begin{array}{l}\text { Percentage } \\
\text { change in inlet } \\
\text { exergy (\%) }\end{array}$ & $\begin{array}{l}\text { Percentage } \\
\text { change in outlet } \\
\text { exergy }(\%)\end{array}$ & $\begin{array}{l}\text { Percentage } \\
\text { change in exergy } \\
\text { efficiency }(\%)\end{array}$ \\
\hline 1 & 13:00 PM-13:10 PM & $\begin{array}{l}30 \\
\text { Increment }\end{array}$ & $\begin{array}{l}20 \\
\text { Decrement }\end{array}$ & $\begin{array}{l}23.7672 \\
\text { Decrement }\end{array}$ & $\begin{array}{l}4.948093 \\
\text { Increment }\end{array}$ & $\begin{array}{l}23.9054 \\
\text { Decrement }\end{array}$ & $\begin{array}{l}27.4931 \\
\text { Decrement }\end{array}$ \\
\hline 2 & 13:10 PM-13:20 PM & $\begin{array}{l}53.8462 \\
\text { Decrement }\end{array}$ & $\begin{array}{l}50 \\
\text { Increment }\end{array}$ & $\begin{array}{l}42.99638 \\
\text { Increment }\end{array}$ & $\begin{array}{l}4.787812 \\
\text { Increment }\end{array}$ & $\begin{array}{l}65.78102 \\
\text { Increment }\end{array}$ & $\begin{array}{l}58.20639 \\
\text { Increment }\end{array}$ \\
\hline 3 & 13:20 PM-13:30 PM & $\begin{array}{l}83.3333 \\
\text { Decrement }\end{array}$ & $\begin{array}{l}16.6667 \\
\text { Decrement }\end{array}$ & $\begin{array}{l}12.7793 \\
\text { Decrement }\end{array}$ & $\begin{array}{l}4.52185 \\
\text { Decrement }\end{array}$ & $\begin{array}{l}11.2253 \\
\text { Decrement }\end{array}$ & $\begin{array}{l}7.02094 \\
\text { Decrement }\end{array}$ \\
\hline 4 & 13:30 PM-13:40 PM & $\begin{array}{l}1700 \\
\text { Increment }\end{array}$ & $\begin{array}{l}100 \\
\text { Increment }\end{array}$ & $\begin{array}{l}96.88037 \\
\text { Increment }\end{array}$ & $\begin{array}{l}1.854385 \\
\text { Increment }\end{array}$ & $\begin{array}{l}111.2407 \\
\text { Increment }\end{array}$ & $\begin{array}{l}107.3948 \\
\text { Increment }\end{array}$ \\
\hline 5 & 13:40 PM-13:50 PM & $\begin{array}{l}94.4444 \\
\text { Decrement }\end{array}$ & $\begin{array}{l}50 \\
\text { Increment }\end{array}$ & $\begin{array}{l}45.45058 \\
\text { Increment }\end{array}$ & $\begin{array}{l}2.829161 \\
\text { Increment }\end{array}$ & $\begin{array}{l}50.91057 \\
\text { Increment }\end{array}$ & $\begin{array}{l}46.75853 \\
\text { Increment }\end{array}$ \\
\hline 6 & 13:50 PM-14:00 PM & $\begin{array}{l}400 \\
\text { Increment }\end{array}$ & No change & $\begin{array}{l}4.83961 \\
\text { Increment }\end{array}$ & $\begin{array}{l}4.49825 \\
\text { Decrement }\end{array}$ & $\begin{array}{l}19.43157 \\
\text { Increment }\end{array}$ & $\begin{array}{l}25.05695 \\
\text { Increment }\end{array}$ \\
\hline 7 & 14:00 PM-14:10 PM & No change & $\begin{array}{l}33.33333 \\
\text { Increment }\end{array}$ & $\begin{array}{l}40 \\
\text { Increment }\end{array}$ & $\begin{array}{l}4.73837 \\
\text { Decrement }\end{array}$ & $\begin{array}{l}45.08877 \\
\text { Increment }\end{array}$ & $\begin{array}{l}52.30557 \\
\text { Increment }\end{array}$ \\
\hline 8 & 14:10 PM-14:20 PM & $\begin{array}{l}200 \\
\text { Decrement }\end{array}$ & No change & $\begin{array}{l}5.06811 \\
\text { Increment }\end{array}$ & $\begin{array}{l}4.97653 \\
\text { Decrement }\end{array}$ & $\begin{array}{l}0.37583 \\
\text { Decrement }\end{array}$ & $\begin{array}{l}4.841649 \\
\text { Increment }\end{array}$ \\
\hline 9 & 14:20 PM-14:30 PM & $\begin{array}{l}20 \\
\text { Increment }\end{array}$ & $\begin{array}{l}400 \\
\text { Increment }\end{array}$ & $\begin{array}{l}400.0928 \\
\text { Increment }\end{array}$ & $\begin{array}{l}0.0494 \\
\text { Decrement }\end{array}$ & $\begin{array}{l}335.906 \\
\text { Increment }\end{array}$ & $\begin{array}{l}336.1214 \\
\text { Increment }\end{array}$ \\
\hline 10 & 14:30 PM-14:40 PM & $\begin{array}{l}75 \\
\text { Increment }\end{array}$ & No change & $\begin{array}{l}5.614331 \\
\text { Increment }\end{array}$ & $\begin{array}{l}5.28657 \\
\text { Decrement }\end{array}$ & $\begin{array}{l}5.81627 \\
\text { Decrement }\end{array}$ & $\begin{array}{l}0.55926 \\
\text { Decrement }\end{array}$ \\
\hline 11 & 14:40 PM-14:50 PM & $\begin{array}{l}100 \\
\text { Decrement }\end{array}$ & No change & $\begin{array}{l}0.01855 \\
\text { Decrement }\end{array}$ & $\begin{array}{l}0.024718 \\
\text { Increment }\end{array}$ & $\begin{array}{l}5.055594 \\
\text { Increment }\end{array}$ & $\begin{array}{l}5.029633 \\
\text { Increment }\end{array}$ \\
\hline 12 & 14:50 PM-15:00 PM & $\begin{array}{l}300 \\
\text { Decrement }\end{array}$ & $\begin{array}{l}50 \\
\text { Decrement }\end{array}$ & $\begin{array}{l}47.1178 \\
\text { Decrement }\end{array}$ & $\begin{array}{l}5.50888 \\
\text { Decrement }\end{array}$ & $\begin{array}{l}47.1588 \\
\text { Decrement }\end{array}$ & $\begin{array}{l}44.0781 \\
\text { Decrement }\end{array}$ \\
\hline 13 & 15:00 PM-15:10 PM & $\begin{array}{l}12.5 \\
\text { Decrement }\end{array}$ & No change & $\begin{array}{l}6.230265 \\
\text { Increment }\end{array}$ & $\begin{array}{l}5.88235 \\
\text { Decrement }\end{array}$ & $\begin{array}{l}5.56573 \\
\text { Decrement }\end{array}$ & $\begin{array}{l}0.336417 \\
\text { Increment }\end{array}$ \\
\hline 14 & 15:10 PM-15:20 PM & $\begin{array}{l}77.7778 \\
\text { Increment }\end{array}$ & No change & $\begin{array}{l}6.805381 \\
\text { Increment }\end{array}$ & $\begin{array}{l}6.22684 \\
\text { Decrement }\end{array}$ & $\begin{array}{l}7.917805 \\
\text { Increment }\end{array}$ & $\begin{array}{l}15.0839 \\
\text { Increment }\end{array}$ \\
\hline 15 & 15:20 PM-15:30 PM & $\begin{array}{l}350 \\
\text { Decrement }\end{array}$ & No change & $\begin{array}{l}7.003705 \\
\text { Increment }\end{array}$ & $\begin{array}{l}6.66667 \\
\text { Decrement }\end{array}$ & $\begin{array}{l}7.60637 \\
\text { Decrement }\end{array}$ & $\begin{array}{l}1.00682 \\
\text { Decrement }\end{array}$ \\
\hline 16 & 15:30 PM-15:40 PM & $\begin{array}{l}111.1111 \\
\text { Decrement }\end{array}$ & No change & $\begin{array}{l}7.49224 \\
\text { Increment }\end{array}$ & $\begin{array}{l}7.11993 \\
\text { Decrement }\end{array}$ & $\begin{array}{l}9.1052 \\
\text { Decrement }\end{array}$ & $\begin{array}{l}2.13746 \\
\text { Decrement }\end{array}$ \\
\hline 17 & 15:40 PM-15:50 PM & $\begin{array}{l}78.9474 \\
\text { Increment }\end{array}$ & $\begin{array}{l}50 \\
\text { Decrement }\end{array}$ & $\begin{array}{l}48.676 \\
\text { Decrement }\end{array}$ & $\begin{array}{l}2.30769 \\
\text { Decrement }\end{array}$ & $\begin{array}{l}48.2083 \\
\text { Decrement }\end{array}$ & $\begin{array}{l}46.9848 \\
\text { Decrement }\end{array}$ \\
\hline 18 & 15:50 PM-16:00 PM & $\begin{array}{l}50 \\
\text { Decrement }\end{array}$ & No change & $\begin{array}{l}5.794047 \\
\text { Increment }\end{array}$ & $\begin{array}{l}5.51181 \\
\text { Decrement }\end{array}$ & $\begin{array}{l}4.80584 \\
\text { Decrement }\end{array}$ & $\begin{array}{l}0.747154 \\
\text { Increment }\end{array}$ \\
\hline
\end{tabular}


Table 4 Percentage changes in various parameters at various time durations for single slope solar still

\begin{tabular}{|c|c|c|c|c|c|c|c|}
\hline Sr. no. & Time durations & $\begin{array}{l}\text { Percentage } \\
\text { change in } \\
\text { increment in } \\
\text { temperature of } \\
\text { water }(\%)\end{array}$ & $\begin{array}{l}\text { Percentage } \\
\text { change in incre- } \\
\text { ment in quantity } \\
\text { of water }(\%)\end{array}$ & $\begin{array}{l}\text { Percentage } \\
\text { change in ther- } \\
\text { mal efficiency } \\
(\%)\end{array}$ & $\begin{array}{l}\text { Percentage } \\
\text { change in inlet } \\
\text { exergy (\%) }\end{array}$ & $\begin{array}{l}\text { Percentage } \\
\text { change in outlet } \\
\text { exergy }(\%)\end{array}$ & $\begin{array}{l}\text { Percentage } \\
\text { change in exergy } \\
\text { efficiency }(\%)\end{array}$ \\
\hline 1 & 11:50 AM-12:00 PM & $\begin{array}{l}56.363636 \\
\text { Decrement }\end{array}$ & $\begin{array}{l}50.0 \\
\text { Decrement }\end{array}$ & $\begin{array}{l}51.979416 \\
\text { Decrement }\end{array}$ & $\begin{array}{l}3.5038469 \\
\text { Increment }\end{array}$ & $\begin{array}{l}51.178527 \\
\text { Decrement }\end{array}$ & $\begin{array}{l}52.831248 \\
\text { Decrement }\end{array}$ \\
\hline 2 & 12:00 PM-12:15 PM & No change & $\begin{array}{l}33.333333 \\
\text { Increment }\end{array}$ & $\begin{array}{l}30.37037 \\
\text { Increment }\end{array}$ & $\begin{array}{l}2.2727273 \\
\text { Increment }\end{array}$ & $\begin{array}{l}43.658515 \\
\text { Increment }\end{array}$ & $\begin{array}{l}40.466104 \\
\text { Increment }\end{array}$ \\
\hline 3 & 12:15 PM-12:30 PM & $\begin{array}{l}70.833333 \\
\text { Decrement }\end{array}$ & $\begin{array}{l}50.0 \\
\text { Decrement }\end{array}$ & $\begin{array}{l}50.704675 \\
\text { Decrement }\end{array}$ & $\begin{array}{l}1.1111111 \\
\text { Increment }\end{array}$ & $\begin{array}{l}50.668673 \\
\text { Decrement }\end{array}$ & $\begin{array}{l}51.210776 \\
\text { Decrement }\end{array}$ \\
\hline 4 & 12:30 PM-12:45 PM & $\begin{array}{l}228.57143 \\
\text { Decrement }\end{array}$ & No change & $\begin{array}{l}2.4405274 \\
\text { Decrement }\end{array}$ & $\begin{array}{l}2.1978022 \\
\text { Increment }\end{array}$ & $\begin{array}{l}5.9648149 \\
\text { Decrement }\end{array}$ & $\begin{array}{l}7.987077 \\
\text { Decrement }\end{array}$ \\
\hline 5 & 12:45 PM-13:00 PM & $\begin{array}{l}22.222222 \\
\text { Decrement }\end{array}$ & $\begin{array}{l}100 \\
\text { Increment }\end{array}$ & $\begin{array}{l}102.09879 \\
\text { Increment }\end{array}$ & $\begin{array}{l}1.026401 \\
\text { Decrement }\end{array}$ & $\begin{array}{l}106.1608 \\
\text { Increment }\end{array}$ & $\begin{array}{l}108.29878 \\
\text { Increment }\end{array}$ \\
\hline 6 & 13:00 PM-13:15 PM & $\begin{array}{l}254.54545 \\
\text { Increment }\end{array}$ & $\begin{array}{l}25.0 \\
\text { Decrement }\end{array}$ & $\begin{array}{l}21.182891 \\
\text { Decrement }\end{array}$ & $\begin{array}{l}4.3478261 \\
\text { Decrement }\end{array}$ & $\begin{array}{l}16.641865 \\
\text { Decrement }\end{array}$ & $\begin{array}{l}12.852858 \\
\text { Decrement }\end{array}$ \\
\hline 7 & 13:15 PM-13:30 PM & $\begin{array}{l}41.176471 \\
\text { Decrement }\end{array}$ & $\begin{array}{l}33.333333 \\
\text { Decrement }\end{array}$ & $\begin{array}{l}34.899177 \\
\text { Decrement }\end{array}$ & $\begin{array}{l}2.2474789 \\
\text { Increment }\end{array}$ & $\begin{array}{l}34.408476 \\
\text { Decrement }\end{array}$ & $\begin{array}{l}35.850228 \\
\text { Decrement }\end{array}$ \\
\hline 8 & 13:30 PM-13:45 PM & $\begin{array}{l}230.0 \\
\text { Decrement }\end{array}$ & No change & $\begin{array}{l}10.638016 \\
\text { Increment }\end{array}$ & $\begin{array}{l}10 \\
\text { Decrement }\end{array}$ & $\begin{array}{l}8.0838628 \\
\text { Decrement }\end{array}$ & $\begin{array}{l}2.1290413 \\
\text { Increment }\end{array}$ \\
\hline 9 & 13:45 PM-14:00 PM & $\begin{array}{l}138.46154 \\
\text { Increment }\end{array}$ & $\begin{array}{l}50.0 \\
\text { Increment }\end{array}$ & $\begin{array}{l}50.501972 \\
\text { Increment }\end{array}$ & $\begin{array}{l}0.0246934 \\
\text { Decrement }\end{array}$ & $\begin{array}{l}52.870879 \\
\text { Increment }\end{array}$ & $\begin{array}{l}52.908638 \\
\text { Increment }\end{array}$ \\
\hline 10 & 14:00 PM-14:15 PM & $\begin{array}{l}280.0 \\
\text { Decrement }\end{array}$ & $\begin{array}{l}33.333333 \\
\text { Decrement }\end{array}$ & $\begin{array}{l}32.675104 \\
\text { Decrement }\end{array}$ & $\begin{array}{l}1.2345679 \\
\text { Decrement }\end{array}$ & $\begin{array}{l}37.065959 \\
\text { Decrement }\end{array}$ & $\begin{array}{l}36.279283 \\
\text { Decrement }\end{array}$ \\
\hline 11 & 14:15 PM-14:30 PM & $\begin{array}{l}105.55556 \\
\text { Decrement }\end{array}$ & $\begin{array}{l}100 \\
\text { Increment }\end{array}$ & $\begin{array}{l}104.76618 \\
\text { Increment }\end{array}$ & $\begin{array}{l}2.451836 \\
\text { Decrement }\end{array}$ & $\begin{array}{l}98.081163 \\
\text { Increment }\end{array}$ & $\begin{array}{l}103.05986 \\
\text { Increment }\end{array}$ \\
\hline 12 & 14:30 PM-14:45 PM & $\begin{array}{l}44.864865 \\
\text { Increment }\end{array}$ & $\begin{array}{l}50 \\
\text { Increment }\end{array}$ & $\begin{array}{l}67.401039 \\
\text { Increment }\end{array}$ & $\begin{array}{l}10.25641 \\
\text { Decrement }\end{array}$ & $\begin{array}{l}47.716307 \\
\text { Increment }\end{array}$ & $\begin{array}{l}64.59817 \\
\text { Increment }\end{array}$ \\
\hline 13 & 14:45 PM-15:00 PM & $\begin{array}{l}157.84314 \\
\text { Decrement }\end{array}$ & $\begin{array}{l}50.0 \\
\text { Decrement }\end{array}$ & $\begin{array}{l}48.683396 \\
\text { Decrement }\end{array}$ & $\begin{array}{l}2.8571429 \\
\text { Decrement }\end{array}$ & $\begin{array}{l}56.216953 \\
\text { Decrement }\end{array}$ & $\begin{array}{l}54.929216 \\
\text { Decrement }\end{array}$ \\
\hline 14 & 15:00 PM-15:15 PM & $\begin{array}{l}17.870722 \\
\text { Decrement }\end{array}$ & No change & $\begin{array}{l}4.5237447 \\
\text { Increment }\end{array}$ & $\begin{array}{l}4.4117647 \\
\text { Decrement }\end{array}$ & $\begin{array}{l}13.317837 \\
\text { Decrement }\end{array}$ & $\begin{array}{l}9.3171217 \\
\text { Decrement }\end{array}$ \\
\hline 15 & 15:15 PM-15:30 PM & $\begin{array}{l}3.2258065 \\
\text { Decrement }\end{array}$ & $\begin{array}{l}33.333333 \\
\text { Increment }\end{array}$ & $\begin{array}{l}49.397414 \\
\text { Increment }\end{array}$ & $\begin{array}{l}10.791259 \\
\text { Decrement }\end{array}$ & $\begin{array}{l}6.7268052 \\
\text { Increment }\end{array}$ & $\begin{array}{l}19.637162 \\
\text { Increment }\end{array}$ \\
\hline 16 & 15:30 PM-15:45 PM & $\begin{array}{l}50.0 \\
\text { Increment }\end{array}$ & No change & $\begin{array}{l}5.7693479 \\
\text { Increment }\end{array}$ & $\begin{array}{l}\text { 5.1489976 } \\
\text { Decrement }\end{array}$ & $\begin{array}{l}2.7024454 \\
\text { Increment }\end{array}$ & $\begin{array}{l}8.2776596 \\
\text { Increment }\end{array}$ \\
\hline 17 & 15:45 PM-16:00 PM & $\begin{array}{l}243.75 \\
\text { Decrement }\end{array}$ & $\begin{array}{l}25.0 \\
\text { Decrement }\end{array}$ & $\begin{array}{l}18.098518 \\
\text { Decrement }\end{array}$ & $\begin{array}{l}9.0909091 \\
\text { Decrement }\end{array}$ & $\begin{array}{l}59.398911 \\
\text { Decrement }\end{array}$ & $\begin{array}{l}55.338802 \\
\text { Decrement }\end{array}$ \\
\hline
\end{tabular}


different phase changing materials and/or effect of preheating of water on the performance of still plants are proposed for comparatively analyses.

Acknowledgements This research work is completed in the Mechanical Engineering Department at Sushila Devi Bansal College of Technology, Indore, India

\section{Compliance with ethical standards}

Conflict of interest The authors declare that they have no conflict of interest.

\section{References}

1. Malik MA (1982) Solar distillation, 1st edn. Elsevier Science \& Technology Books, London

2. Garg HP, Prakash J (2000) Solar energy: fundamentals and applications, 1st edn. Tata McGraw Hill Education Publication, New Delhi

3. Tiwari GN (2008) Solar energy: fundamentals, design, modelling and applications, 1st edn. Narosa Book Distributors Pvt. Ltd., New Delhi

4. Sukhatme SP, Nayak JK (2011) Solar energy principles of thermal collection and storage, 3rd edn. The McGraw Hill Companies, New Delhi

5. Nafey AS, Abdelkader M, Abdelmotalib A, Mabrouk AA (2000) Parameters affecting solar still productivity. Energy Convers Manag 41(16):1797-1809. https://doi.org/10.1016/S0196 -8904(99)00188-0

6. Singh HN, Tiwari GN (2004) Monthly performance of passive and active solar stills for different Indian climatic conditions. Desalination 168:145-150. https://doi.org/10.1016/j.desal.2004.06.180

7. Abdallah S, Badran O, Abu-Khader M (2008) Performance evaluation of a modified design of a single slope. Desalination 219:222-230

8. Medugu DW, Ndatuwong LG (2009) Theoretical analysis of water distillation using solar still. Int J Phys Sci 4(11):705-712

9. Radwan SM, Hassanin AA, Abu-zeid MA (2009) Single slope solar still for sea water distillation. World Appl Sci J 7(4):485-497

10. Arjuna TV, Aybar HS, Nedunchezhian N (2009) A study on effects of water capacity on the performance of a simple solar still. Int J Appl Eng Res 4(11):2223-2234

11. Afrand M, Behzadmehr A, Karimipour A (2010) A Numerical simulation of solar distillation for installation in ChabaharIran. World Acad Sci Eng Technol Int J Mech Mechatron Eng 4(11):1251-1256

12. Prasad PR, Pujitha P, Rajeev GV, Vikky K (2011) Energy efficient solar water still. Int J ChemTech Res 3(4):1781-1787

13. Shabibi AMA, Tahat M (2015) Thermal performance of a single slope solar water still with enhanced solar heating system. In: International conference on renewable energies and power quality (ICREPQ'15) La Coruña (Spain), 25-27, 2015, 10(13):585587. https://doi.org/10.24084/repqj13.417

14. Joshi U, Geete A (2016) Numerical simulation on effect of climate \& design parameters on the single slope solar still. Int J Eng Assoc 5(5):6-10

15. Murugavel KK, Sivakumar S, Ahamed JR, Chockalingam Kn KSK, Srithar K (2010) Single basin double slope solar still with minimum basin depth and energy storing materials. Appl Energy 87(2):514-523
16. Panchal HN (2011) Experimental investigation of varying parameters affecting on double slope single basin solar still. Int J Adv Eng Sci 2:17-21

17. Zeroual Bechki D, Boughali S (2011) Experimental investigation on a double slope solar still with partially cooled condenser in the region of Ouargla. Energy Procedia 6:736-742

18. Elango T, KalidasaMurugavel K (2015) The effect on water depth on the productivity of the single slope and double slope solar stills. Desalination 359:82-91

19. Castillo-Tellez M, Pilatowshy-Figueroa I, Sanchez-Juarez A (2015) Experimental study on air velocity effect on the efficiency and fresh water production in a forced convective double slope solar still. Appl Therm Eng 75:1192-1200

20. Pal P, Dev R (2016) Experimental study on modified double slope solar still and modified basin type double slope multiwick solar still. World Acad Sci Eng Technol Int J Civ Environ Eng 10(1):70-75

21. Elangovan T, Mohanraj R, Manikandan G, Mohanasundram S, Manigandan V (2018) Performance investigation on double slope solar still. Int J Sci Res Dev 5(11):94-97

22. Elbar ARA, Yousef MS, Hassan H (2019) Energy, exergy, exergoeconomic and enviroeconomic (4E) evaluation of a new integration of solar still with photovoltaic panel. J Clean Prod 233:665-680. https://doi.org/10.1016/j.jclepro.2019.06.111

23. Kabeel AE, Abdelaziz GB, El-Said EMS (2019) Experimental investigation of a solar still with composite material heat storage: energy, exergy and economic analysis. J Clean Prod 231:21-34. https://doi.org/10.1016/j.jclepro.2019.05.200

24. Yousef MS, Hassana $\mathrm{H}$ (2019) Assessment of different passive solar stills via exergoeconomic, exergoenvironmental, and exergoenviroeconomic approaches: a comparative study. Sol Energy 182:316-331. https://doi.org/10.1016/j.solener.2019.02.042

25. Bait O (2019) Exergy, environ-economic and economic analyses of a tubular solar water heater assisted solar still. J Clean Prod 212:630-646. https://doi.org/10.1016/j.jclepro.2018.12.015

26. Sharshir SW, Peng G, Elsheikh AH, Edreis EMA, Eltawili MA, Abdelhamid T, Kabeel AE, Zang J, Yang N (2018) Energy and exergy analysis of solar stills with micro/nano particles: a comparative study. Energy Convers Manag 177:363-375. https://doi. org/10.1016/j.enconman.2018.09.074

27. Kabeel AE (2009) Performance of solar still with a concave wick evaporative surface. Energy 34:1504-1509

28. Wassouf P, Peska T, Singh R, Akbarzadeh A (2011) Novel and low cost design of portable solar stills. Desalination 276:294-302

29. Rajamanickam M, Ragupathy A (2012) Influence of water depth on internal heat and mass transfer in a double slope solar still. Energy Procedia 14:1701-1708

30. Kumar AT, Jayaprakash R, Denkenberger D, Ahsan A, Okundamiya MS, Kumar S (2012) An experimental study on a hemispherical solar still. Desalination 286:342-348

31. Ahsan A, Imteaz M, Thomas U, Azmi M, Rahman A, Daud N (2014) Parameters affecting the performance of a low cost solar still. Appl Energy 114:924-930

32. Kumar AT, Jayaprakash $R$, Ahsan A, Denkenberger D, Okundamiya MS (2013) Effect of water and air flow on concentric tubular solar water desalting system. Appl Energy 103:109-115

33. Velmurugan V, Deendayalan CK, Vinod H, Srithar K (2008) Desalination of affluent using fin type solar still. Energy 33:1719-1727

34. Geete A, Sharma R (2019) Experimental exergy analyses on fabricated parabolic solar collector with/without preheater and different collector materials. Int J Ambient Energy 40(6):577-589. https://doi.org/10.1080/01430750.2017.1422144

35. Geete A, Dubey A, Sharma A, Dubey A (2018) Exergy analyses of fabricated compound parabolic solar collector with evacuated tubes at different operating conditions: Indore (India). J Inst 
Eng India Ser C 100(3):455-460. https://doi.org/10.1007/s4003 2-018-0455-5

36. Geete A (2019) Exergy analyses for parabolic solar collector at different conditions: PAPSC software. J Sol Energy Res 4(1):41-52

37. Geete A, Kothari S, Sahu R, Likhar P, Saini A, Singh A (2016) Experimental analysis on fabricated parabolic solar collector with various flowing fluids and pipe materials. Int J Renew Energy Res 6(4):1454-1463

38. Sharma R, Geete A (2017) Experimental analyses on parabolic solar collector at various operating conditions. Univers J Mech Eng 5(2):25-34. https://doi.org/10.13189/ujme.2017.050201

39. Nag PK (2018) Engineering thermodynamics, 6th edn. Tata McGraw Hill Publication, New Delhi

40. Eastop TD (2009) Applied thermodynamics for engineering technologists, 5th edn. Dorling Kindersley Pvt. Ltd., Pearson Education, Noida

41. Potter MC, Somerton CW (1995) Schaum's outline of theory and problems of thermodynamics for engineers. Mc-Graw Hill Publication, New York

42. Singh O (2009) Applied thermodynamics, 3rd edn. New Age International Publication, New Delhi

43. Geete A (2020) Performance analyses of coal-fired thermal power plant using parabolic solar collectors for feed water heaters. Aust J Mech Eng. https://doi.org/10.1080/14484 846.2019.1706226

44. Ismail BI (2009) Design and performance of a transportable hemispherical solar still. Renew Energy 34:145-150

45. Varol HS, Yazar A (1996) A hybrid high efficiency single-basin solar still. Int J Energy Res 20:541-546

46. Minasian AN, Al-Karaghouli AA (1995) An improved solar still: the wick-basin type. Energy Convers Manag 36:213-217
47. Sahoo BB, Sahoo N, Mahanta P, Kalita P, Borbora L, Saha UK (2008) Performance assessment of a solar still using blackened surface and thermocol insulation. Renew Energy 33:1703-1708

48. Sodha MS, Kumar A, Tiwari GN, Tyagi RC (1981) Simple multiple wick solar still: analysis and performance. Sol Energy 26:127-131

49. Sakthivel M, Shanmugasundaram S, Alwarsamy T (2010) An experimental study on a regenerative solar still with energy storage medium - Jute cloth. Desalination 264:24-31

50. Cappelletti GM (2002) An experiment with a plastic solar still. Desalination 142:221-227

51. Al-Karaghouli AA, Alnaser WE (2004) Performances of single and double basin solar stills. Appl Energy 78:347-354

52. Al-Hayek I, Badran OO (2004) The effect of using different designs of solar stills on water distillation. Desalination 169:121-127

53. Nijmeh S, Odeh S, Akash B (2005) Experimental and theoretical study of a single basin solar still in Jordan. Int Commun Heat Mass Transf 32:565-572

54. Bassam AK, Abu-Hijleh Hamzeh M R (2003) Experimental study of a solar still with sponge cubes in basin. Energy Convers Manag 44:1411-1418

55. Flendrig LM, Shah B, Subrahmaniam N, Ramakrishnan V (2009) Low cost thermoformed solar still water purifier for D\&E countries. Phys Chem Earth Parts A/B/C 34:50-54

56. Kumar VK, Bai KR (2008) Performance study on solar still with enhanced condensation. Desalination 230:51-61

Publisher's Note Springer Nature remains neutral with regard to jurisdictional claims in published maps and institutional affiliations. 